\title{
The Effect of Organic and Inorganic Fertilizers Application on Vegetative Growth, Yield and Its Components, and Chemical Composition of Two Potato (Solanum tuberosum, L.) Cultivars
}

\author{
Zohair Mahmoud Mirdad ${ }^{1}$
}

\begin{abstract}
Two winter field experiments were carried out at the Agricultural Research Experiment Station, King Abdulaziz University, Hada-Alsham, Saudi Arabia, during the two years of 2007 and 2008 , in order to assess the response of the two potato cultivars Diamont and Nicola to two rates of chicken manure $\left(15\right.$ and $\left.30 \mathrm{~m}^{3} \mathrm{ha}^{-1}\right)$ as well as control treatment (without addition), three levels of mineral NPK fertilizer (200-100-100, 300-150-150 and 400200-200 kg N-P $\mathrm{O}_{5}-\mathrm{K}_{2} \mathrm{O} \mathrm{ha}^{-1}$ ) in addition to control (without application), and their combinations on vegetative growth, yield and its components, and chemical compositions characters of potato.

The obtained results indicated generally that the comparisons among the mean values of the studied vegetative growth, yield and chemical composition for each factor (main effects) appeared to be significant in most cases, during the two growing seasons. The results illustrated also that the cultivar Diamont gave the highest mean values of all studied characters, with few exceptions, in both seasons. An application of either organic manure at the rate of $15 \mathrm{~m}^{3} . \mathrm{ha}^{-1}$ or mineral NPK at the level of $300-150-150 \mathrm{~kg} . h a^{-1}$ gave significantly the highest mean values of most studied vegetative growth, yield and its components and chemical compositions, during the two years.

The results concerning the first-order interaction indicated that the combination between cultivar Diamont and either of organic manure at the rate of $15 \mathrm{~m}^{3} \mathrm{ha}^{-1}$ or mineral NPK fertilizer at the rate of $300-150-150 \mathrm{~kg} \mathrm{ha}^{-1}$, and the interaction effects between the treatment combination of organic manure and mineral NPK fertilizer at such rates, resulted in the highest significant mean values of the vegetative growth characters, most of the studied yield components and some of chemical compositions, in the two seasons.

The obtained results indicated also that the treatment combination of cultivar Diamont with organic manure at the rate of $15 \mathrm{~m}^{3} \mathrm{ha}^{-1}$ plus mineral NPK fertilizer at the level of 300-150-150 kg N-P $\mathrm{O}_{5}-\mathrm{K}_{2} \mathrm{O}$ ha. ${ }^{-1}$, gave the best second-order interaction treatment for most studied vegetative growth, all potato yield and its component characters, and some of the chemical composition parameters, during the two growing seasons of the years 2007 and 2008.
\end{abstract}

\section{INTRODUCTION}

\footnotetext{
${ }^{1}$ Faculty of Meteorology, Environment and Arid Land Agriculture,

King Abdulaziz University, Jeddah, Saudi Arabia

Received March 8, 2010, Accepted March 29, 2010
}

Potato (Solanum tuberosum, L.) is considered as one of the most important vegetable food crops all over the world, As a world crop, it ranks the first most important tuber crop, and next to wheat and rice (Alam et al. 2007). Potato tubers are an important source of digestible carbohydrates, dietary fiber, vitamin C, and some necessary minerals (Sarhan et al. 2004). So, it can use as a staple food, vegetable, source of starch, flour, alcohol, acetone and glucose.

Nitrogen $(\mathrm{N})$, Phosphorus $(\mathrm{P})$ and potassium (k) are considered as the most three important elements prerequisite for plant nutrition in large amounts. They play essential roles in overall metabolism of plant enzymes activity, promoting photosynthesis, cell divisive and development of meristematic tissue, nitrogen and water consumption respiration. Since, nitrogen $(\mathrm{N})$ is an essential element for building up protoplasm, proteins and amino acids, which induce cell division and initiate meristematic activity. Also, phosphorus is a part of molecular structure of nucleic acid (DNA and RNP), the energy transfer compounds and phosphor-proteins. Moreover, potassium element is very important in overall metabolism of plant enzymes activity. It is important to serve a vital role in photosynthesis by direct increasing in growth and leaf area and hence $\mathrm{CO}_{2}$ assimilation (Gardener et al. 1985).

The effects of the three mineral fertilizers nitrogen $(\mathrm{N})$, phosphorus $(\mathrm{P})$ and potassium $(\mathrm{K})$ individually or in combination with either one or more of each potato cultivar plants were reported by several investigations such as: Brijlal and Sharma (1995) using K; Danilchenko et al. (2005) and Alam et al. (2007) using NPK. Since, they found that using such fertilizers reflected significant effects on the vegetative, yield and chemical compositions characters of potato plants.

It is well known that organic manure improved the structure of the soil and this consequently encourage the plant to have a good growth. Moreover, the slow released nutrients contained in organic manure permit the plants to beneficial of it. All these reasons resulted in improve plant growth. Such results were illustrated by: Filip and Muller (1984), Kadhim (1986), Borin et al. (1987) and Moustafa (1994). The value of organic 
fertilizers as a source of nutrients for potato plants has been revived by several investigators such as: Striban $e t$ al. (1984); Tashkhodzhaev (1985); Borin etal. (1987); Reichbuch etal. (1989); Grewal (1990) and Blecharczyk and Shrzyczak (1996).Studies were also made by several researchers on the effects of organic and inorganic fertilizers on vegetative growth, yield, and chemical compositions of potato, such as; Spoil and Fedotova (1987); Das and Banerjee (1996); Eiecharczyk and Malecka (2000); Danilchenko etal.(2005) and Singh and Kushwah (2006).

Therefore, the main objective of this study was to investigate the main effects of potato cultivars, organic manure and inorganic NPK, and their interactions on growth, yield and its components, and chemical composition of potato plants.

\section{MATERIALS AND METHODS}

Two field experiments were carried out during the two consecutive winter seasons of 2007 and 2008 at the Agricultural Research Experiment Station, King Abdulaziz University, Hada-Alsham, Saudi Arabia.

In both experiments, the used experimental layout was split-split plot system in a randomized complete blocks design(RCBD) with three replications. Each replicate consisted of twenty four treatments; which representing the combinations among the three factors; the first one was two cultivars of potato (Nicola and Diamont). The second one was two rates of chicken manure as well as control $\left(0,15\right.$ and $\left.30 \mathrm{~m}^{3} / \mathrm{ha}\right)$. The third factor was three levels of mineral NPK fertilizers as well as control (0-0-0, 200-100-100, 300-150-150 and 400-200-200) $\mathrm{kg} \mathrm{N}-\mathrm{P}_{2} \mathrm{O}_{5}-\mathrm{K}_{2} \mathrm{O}$ ha $^{-1}$.

The forms of the three mineral fertilizers types; NPK; were used as follows; ammonium nitrate $(33.50 \%$ $\mathrm{N})$, calcium super phosphate $\left(\begin{array}{lll}15.5 \% & \left.\mathrm{P}_{2} \mathrm{O}_{5}\right) & \text { and }\end{array}\right.$ potassium sulphate $\left(48 \% \quad \mathrm{~K}_{2} \mathrm{O}\right)$. Regarding the arrangement of the different treatments, the two cultivars were setted as the main plots and organic manure was considered as the sub-plots; whereas, mineral fertilizer levels were taken as the sub-sub plots. Each experimental unit area was $8.4 \mathrm{~m}^{2}$, including three rows, four meters long and $70 \mathrm{~cm}$ width, with plant spacing $25 \mathrm{~cm}$. A guard row was left without planting to separate each adjacent sub-sub plots. The same experimental steps were conducted in the first and the second seasons of 2007 and 2008, respectively.

Prior to the initiation of each experiment, soil samples were collected and analyzed according to the published method Al-Solaimani et al. (2009). The results of the soil analyses are given in Table 1-a and 1b,as average for the two seasons of 2007 and 2008 .

Soil $\mathrm{pH}$ and electrical conductivity (EC) were determined by mixing soil with water by $1: 1$ weightvolume $(\mathrm{W}: \mathrm{V})$ ratio using glass rod. The total organic matter (O.M.) in the soil was determined using Walkeley and Black's method as described by Jackson (1973). The soil nitrogen was estimated according to the method of Bremner (1965). The soil nitrogen content was measured by Kjeletec Auto 1030 analyzer. The total quantities of phosphorous, potassium, calcium, magnesium and sodium were determined after they were extracted by digestion method with perchloric and nitric acids method as described by Shelton and Harper (1941). Phosphorous content was determined at light wave length 640 manometer, using Turner spectrophotometer model 2000, whereas, potassium calcium, magnesium and sodium concentrations were measured in the extraction using Perkin Elmer 5000 AAS. The chemical properties of the used organic manure (chicken manure) was presented in Table 2.

With respect to the rates of organic manure were randomly applied to the surface of each row and incorporated well to about $15-30 \mathrm{~cm}$ depth of the soil before planting of potato pieces. Concerning the planting potato, the potato tubers of each cultivar were separately cut into pieces (about $60 \mathrm{~g}$ ), then they planted on one side of the row at $25 \mathrm{~cm}$ apart on Jan 4 and Jan 2 of the two years of 2007 and 2008, respectively.

Pertaining to the rates of the used mineral fertilizers of each nitrogen and potassium rates were divided into three equal quantities through the growing stages.

Table 1.a. Average soil texture and physical properties of soil analysesof the two seasons of 2007 and 2008

\begin{tabular}{ccccc}
\hline Depth (cm) & Loam (\%) & Silt (\%) & Sand (\%) & Soil texture \\
\hline $0-15$ & 9.1 & 5.54 & 85.36 & S.L \\
\hline $15-30$ & 3.40 & 8.2 & 88.4 & S \\
\hline
\end{tabular}

Table 2. Average chemical analysis for soil samples from field experiment of the two seasons of 2006 and 2007

\begin{tabular}{ccccccccccccc}
\hline $\begin{array}{c}\text { Depth } \\
(\mathbf{c m})\end{array}$ & $\begin{array}{c}\mathbf{O} . \mathbf{M} \\
(\boldsymbol{\%})\end{array}$ & $\mathbf{p H}$ & $\begin{array}{c}\mathbf{E C} \\
\mathbf{d S m}^{-1}\end{array}$ & $\begin{array}{c}\mathbf{N} \\
\mathbf{M g} / \mathbf{l}\end{array}$ & $\begin{array}{c}\mathbf{P} \\
\mathbf{M g} / \mathbf{l}\end{array}$ & $\begin{array}{c}\mathbf{K} \\
\mathbf{M g} / \mathbf{l}\end{array}$ & $\begin{array}{c}\mathbf{C a} \\
\mathbf{M g} / \mathbf{l}\end{array}$ & $\begin{array}{c}\mathbf{N a} \\
\mathbf{M g} / \mathbf{l}\end{array}$ & $\begin{array}{c}\mathbf{M g} \\
\mathbf{M g} / \mathbf{l}\end{array}$ & $\begin{array}{c}\mathbf{C l} \\
\mathbf{M g} / \mathbf{l}\end{array}$ & $\begin{array}{c}\mathbf{S O}_{4} \\
\mathbf{M g} / \mathbf{l}\end{array}$ & $\begin{array}{c}\mathbf{H S O}_{3}^{-} \\
\mathbf{M g} / \mathbf{l}\end{array}$ \\
\hline $0-15$ & 2.1 & 7.5 & 1.99 & 0.21 & 0.03 & 0.37 & 0.96 & 0.98 & 1.89 & 1.41 & 0.94 & 2.1 \\
\hline
\end{tabular}




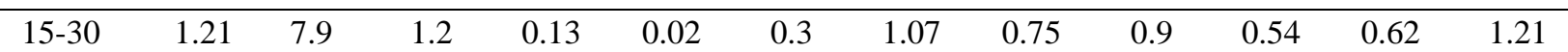

Table 2. Chemical analysis of the used chicken manure

\begin{tabular}{|c|c|c|c|c|c|c|c|c|c|c|c|c|}
\hline Properties & pH & $\begin{array}{l}\text { Moisture } \\
\text { content } \\
\text { (\%) (M.C.) }\end{array}$ & $\begin{array}{l}\text { EC } \\
\text { (ds.m) }\end{array}$ & $\begin{array}{l}\text { T.S. } \\
\%\end{array}$ & $\begin{array}{l}\text { C/N } \\
\text { Ratio }\end{array}$ & $\begin{array}{l}\text { O.M. } \\
\%\end{array}$ & $\begin{array}{l}\text { Ash } \\
\%\end{array}$ & $\begin{array}{l}\text { Total } \\
\text { N(\%) }\end{array}$ & $\begin{array}{l}\text { Total } \\
\text { P(\%) }\end{array}$ & $\begin{array}{c}\text { TotalK } \\
(\%)\end{array}$ & $\begin{array}{l}\mathrm{Ca} \\
(\%)\end{array}$ & $\begin{array}{l}\mathrm{Mg} \\
(\%)\end{array}$ \\
\hline $\begin{array}{l}\text { Chemical } \\
\text { analyses }\end{array}$ & 7.92 & 12.65 & 4.85 & 1.04 & $12: 1.00$ & 55.03 & 38.29 & 1.96 & 2.77 & 2.55 & 5.02 & 0.46 \\
\hline
\end{tabular}

The first addition was added after two weeks from planting; the second portion was added after five weeks from planting date; whereas, the last one was performed during tubering stage. Phosphorus fertilizer rates were added completely in the first addition. During the growing seasons, all other recommended agro managements such as irrigation, diseases, pests and weeds control programs were performed whenever they appeared to be necessary.

\section{Data Recorded}

Five plants were randomly selected from the central two rows of each sub-sub-plot, during the growing season, to measure the observations based on the morphological characteristics, i.e., vegetative growth, yield and its components, and some chemical components of leaves and tubers as follows:

\section{Vegetative growth characters}

Samples of five plants were randomly chosen from the middle two rows of each sub-sub-plot, at the beginning of tuberous stems formation. The five selected plants were cut off at the ground level to measure the studied vegetative growth parameters as follows: plant height $(\mathrm{cm})$, number of aerial stems per plant, foliage fresh weight per plant $(\mathrm{g})$, and leaves dry matter content $(\%)$.

\section{Tubers yield and its components:}

At maturity stage, about 120 days after planting time, tuberous stems were dug from the central two rows of each sub-sub-plot, were collected. Then, the following data were recorded, tuber fresh weight $(\mathrm{g})$, number of tubers plant ${ }^{-1}$, tubers weight plant $^{-1}$ and tuber dry matter content $(\%)$.

\section{Tubers stems quality:}

Tubers stems quality was expressed by the tubers constituents of total sugars, starch, and carbohydrates (\%). Directly after harvesting, five tubers samples were randomly bulked from each experimental unit to determine such compositions. Such samples of dried tubers, as previously mentioned were taken, ground into fine powder with a grinder for total sugars, starch and carbohydrates constituents. Sucrose concentration (\%) was estimated by using the procedure of Association of Official Analytical Chemists (A.O.A.C., 1980). Then, they measured calorimetrically, using a spectrophotometer at $540 \mathrm{~nm}$. Total sugars contents were estimated by the summation of the reducing sugars and sucrose. Starch content was determined by using the method of phenol sulphonic acid as described by Malik and Singh (1980). Carbohydrates content were obtained by the summation of both total sugars and starch contents.

\section{Chemical constituents of leaves:}

A random sample of leaves from each sub-sub plot was collected, washed with distilled water, oven dried at $70^{\circ} \mathrm{C}$ to a constant weight, and then ground into fine powder. The ground tissues of the leaves were analyzed for determining the concentrations of $\mathrm{N}, \mathrm{P}$ and $\mathrm{K}$. Nitrogen content was determined using the Semi-Micro Kjeldohl method as described in A.O.A.C. (1980). Phosphorus content was determined using stannous chloride method; while, potassium content was measured using Flam photometer (Toth et al., 1948).

\section{Statistical analysis:}

All obtained data were collected and statistically analyzed, using Co-Stat Software (2004), computer program for statistics. Duncan's multiple range test was used to compare the differences among the means of the treatments as elucidated by Steel and Torrie (1984).

\section{RESULTS AND DISCUSSIONS}

\section{Main Effects of the Different Factors on the Studied Characters:}

The results of the main effects of the different studied factors; i.e., cultivars, organic manure and mineral NPK fertilizers; on vegetative growth, yield, yield components, and chemical composition of leaves and tubers characters of potato are shown in Tables 3, 4 and 5 .

\section{Vegetative growth characters:}

Concerning the main effects of the three studied factors; i.e., two cultivars, three organic manure rates and four mineral NPK fertilizer levels; on vegetative growth characters of potato plants, the results illustrated generally that the comparisons among the mean values of the studied characters for each factor appeared to be significant, in both growing seasons (Table 3 ).

The obtained results concerning the main effects of potato cultivars illustrated generally that the used 
cultivars differed significantly in all the studied vegetative growth characters, in both growing seasons. Cultivar Diamont gave the highest mean values of the characters plant height, number of aerial stems plant $^{-1}$, and foliage fresh weight plant $^{-1}$; whereas, cultivar Nicola gave the highest value of the leaves dry matter content parameter, in the two years (Table 3). Such results meant, generally, that the evaluated cultivars varied in their general performances with respect to those characters. The obtained results concerning the vegetative growth characters seemed to cope with the findings of several investigators such as: Widdowson and Penny (1975); El-Nashar et al. (1995); Marwaha (1998) and Swaminathan et al. (1999). Since, they showed that potato cultivars differed significantly from each other in vegetative growth characters of potato plants.

With respect to the main effects of organic manure on the vegetative growth characters, the results in Table 3 showed that application of organic manure at the rate of $15 \mathrm{~m}^{3}$ ha. $^{-1}$ significantly increased all the studied vegetative growth characters, compared to control, in both growing seasons. The results in Table 3 illustrated generally that using organic manure either at rate of 15 $\mathrm{m}^{3}$ ha. $^{-1}$ or $30 \mathrm{~m}^{3}$ ha. $^{-1}$ reflected significant differences among the mean values of the characters plant height, number of aerial stems plant ${ }^{-1}$, foliage fresh weight plant $^{-1}$ and leaves dry matter content, in the two growing seasons. Such results indicated generally that the potato cultivars responded well to application of organic manure. The obtained results suggested generally that increasing the morphological characters of potato after the application of organic manure application may be due to increasing the soil organic matter content, cation exchange capacity and mineral nutrients, which in turn encouraged the plant growth to go forward. In this respect, Ashour and Sarhan (1998) found that application of organic manure significantly increased foliage fresh weight plant $^{-1}$ and plant height characters of potato. Similar findings were also reported by Abou-El-Salehein et al. (1999) for plant height and leaves dry matter content; El-Morsy et al. (2006) for plant height, number of main stems plant ${ }^{-1}$ and foliage fresh weight plant ${ }^{-1}$, and Alam et al. (2007) for plant height and number of main stems plant ${ }^{-1}$, who stated that application of organic manure fertilizer to potato plants increased the vegetative growth characters.

As for the mineral NPK fertilizer effects on the vegetative growth characters, the results reflected generally that using the different levels of mineral NPK fertilizer resulted in increasing effects on the characters plant height, number of aerial stems plant $^{-1}$, foliage fresh weight plant $^{-1}$ and leaves dry matter; comparing to control treatment, in both seasons. The simulative effects of NPK on growth parameters may be due to that nitrogen is an essential element for building up protoplasm, amino acids and proteins, which induce cell division and initiate meristematic activity; phosphorus is a part of molecular structure of nucleic acid (DNA and RNA), the energy transfer compounds and phosphor-proteins. Moreover, potassium is very important in activity, it was found to serve a vital role in photosynthesis by direct increasing in growth and leaf area and hence $\mathrm{CO}_{2}$ assimilation (Gardener et al. 1985).

The application of inorganic NPK fertilizer at the rate of $300-150-150 \mathrm{~kg}$ ha. ${ }^{-1}\left(\mathrm{~N}_{2}-\mathrm{P}_{2}-\mathrm{K}_{2}\right)$ to the grown potato plants, significantly, gave taller plants, more number of aerial stems plant ${ }^{-1}$, and attained heavier foliage fresh weight plant $^{-1}$ and leaves dry matter content, compared with those of either control $\left(\mathrm{P}_{0^{-}}-\mathrm{P}_{0^{-}}\right.$ $\left.\mathrm{K}_{0}\right)$ or the other two levels $\left(\mathrm{N}_{1}-\mathrm{P}_{1}-\mathrm{K}_{1}\right.$ and $\left.\mathrm{N}_{3}-\mathrm{P}_{3}-\mathrm{K}_{3}\right)$, in the two seasons of 2007 and 2008. Results obtained by many investigators seemed to confirm the obtained findings (Rabie, 1996; Ashour and Sarhan, 1998; Sarhan et al., 2004, and Alam et al., 2007). Since, they found that application of NPK resulted in significant increases in their studied vegetative growth characters of potato plants.

\section{Yield and its components:}

Regarding the results of the main effects of cultivars, organic manure and mineral NPK fertilizers on the yield and its components are presented in Table 4. The obtained results reflected that the highest mean value of the characters tuber fresh weight, number of tubers plant ${ }^{-1}$, tubers weight plant and tuber dry matter content was given by the cultivar Diamont, compared to the cultivar Nicola, in both years. Similar findings were also reported by several researchers such as Marwaha (1998); Swaminathan et al., (1999) and Shafeek et al., (2001), who found that the evaluated potato cultivars in their studied, significantly, differed from one another.

Concerning the main effects of organic manure on yield characters, the results illustrated generally that application of organic manure reflected increasing effects on the mean values of all the studied yield and its component characters, in the two seasons. These results are in correspondence with those obtained byArisha and Bardisi (1999) and Awad et al. (2002) on potato plants Also, such results are in agreement with the findings of several researchers, who found that application of organic manure to potato plants gave significant effects on yield and its components characters (Karmanov and Gushchina, 1986; Saghin, 1989, Sood et al., 1994, Reche et al., 1997; Kabeel and Hasanin, 2006; and Alam et al., 2007). The application of organic manure at the rate of $15 \mathrm{~m} 3$ ha. $^{-1}(\mathrm{O}-2)$ reflected the best treatment, which gave the highest 
mean values for the yield and its components

O-2), in the two seasons. characters, comparing with the other two rates $(\mathrm{O}-1$ and

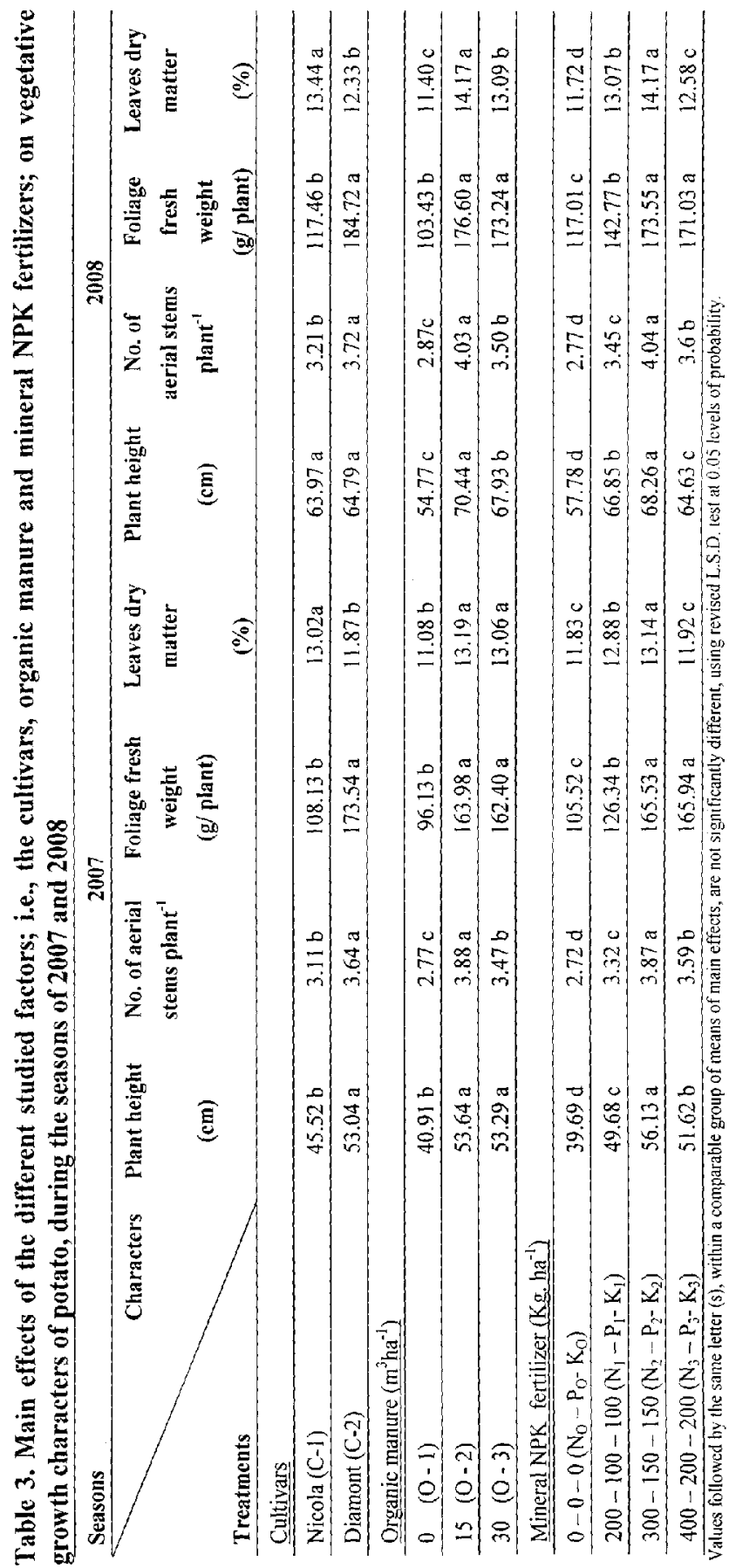




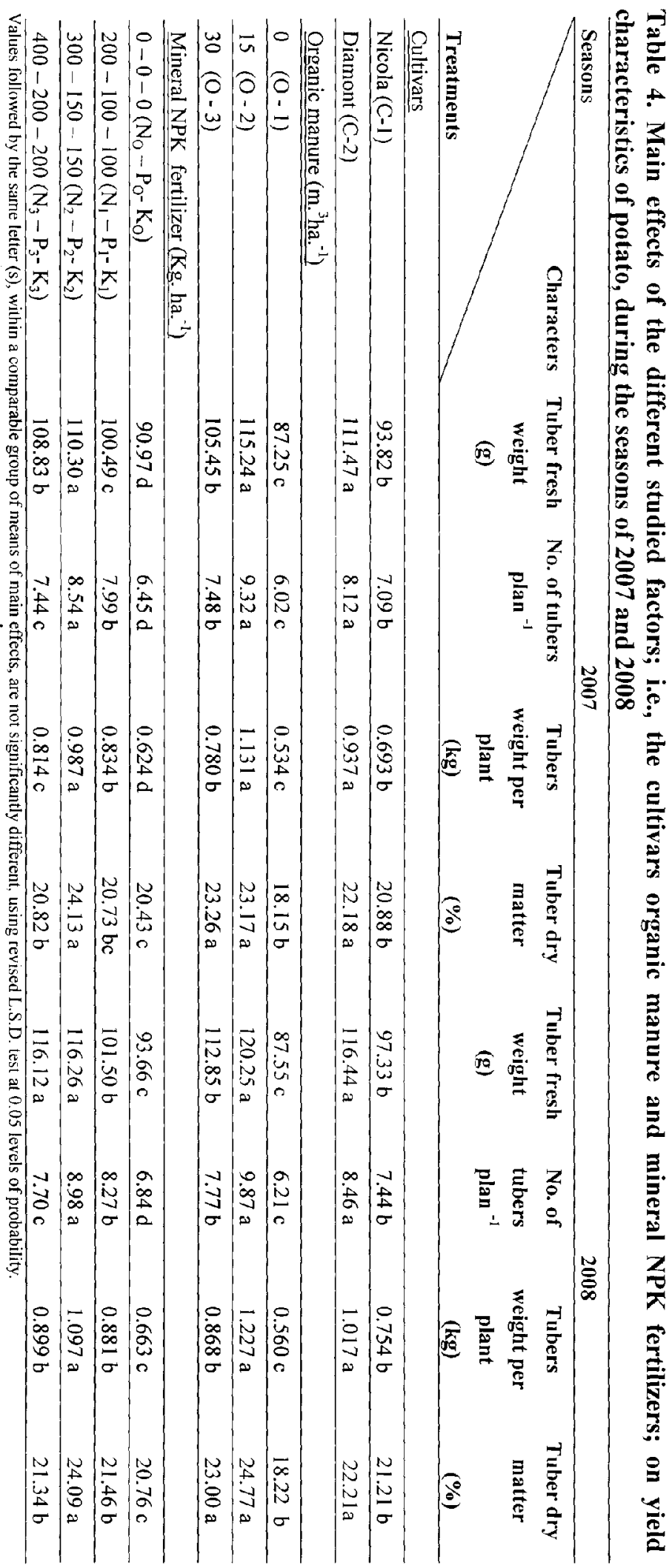


The favorable influences of organic manure application on tuberous yield and its components could be related to the vital role of organic manure in increasing the availability of nutrient supply, improve the efficiency of macro-elements as well as its ability to meet some micro-elements requirement of crop, which in turn, should be reflected on production of high yield.

The results of the main effects of mineral NPK fertilizer levels on yield and its components characters illustrated generally that the comparisons among the mean values of each studied character were high enough to significant, in the two growing seasons. The results showed also that increasing mineral NPK fertilizer application up to $300-150-150 \mathrm{~kg} \mathrm{ha}^{-1}$ gave increasing effects on the yield and its components characters. The application of mineral NPK fertilizer at the rate of $300-150-150 \mathrm{~kg} \mathrm{ha}^{-1}\left(\mathrm{~N}_{2}-\mathrm{P}_{2}-\mathrm{K}_{2}\right)$ was the most favorable treatment that gave the significant highest mean values of all the studied yield and its components characters, in the seasons of 2007 and 2008. On the other side, application of NPK fertilizer with high level (400-200-200 kg ha. ${ }^{-1}$ ) resulted in decreasing effects on the studied yield and its component characters, in the two seasons. These results were generally in accordance with those reported by Adhikari and Sharma (2004); Danilchenko et al. (2005); Singh and Kushwah (2006), who found that increasing the application of NPK fertilizer resulted in increasing the potato yield and its component characters of potato. Similar trends were also obtained by Ashour and Sarhan (1998); and Alam et al. (2007), who found that using high rates of mineral NPK reflected increasing effects on yield and its components characters of potato.

\section{Chemical compositions:}

Pertaining the results of main effects of each studied factor on the chemical compositions of leaves and tubers of potato are shown in Table 5. Concerning the main effects of the cultivars on chemical parameters of potato, the results reflected significant differences among the values of each studied parameter in most cases, but, with different magnitudes, in the two winter seasons.

In the first season of 2007, the differences between the mean values of $\mathrm{N} \%, \mathrm{P} \%$ and total sugars were not high enough to be significant, as affected by the different two cultivars Nicola and Diamont; whereas, significant effects on $\mathrm{K} \%$, starch and carbohydrates contents were detected. In the second season of 2008, the comparisons between the two cultivars for the values of all the studied chemical parameters appeared to be insignificant, with only one exception. This exception was $\mathrm{K} \%$, which reflected significant difference between the two cultivars for this parameter. Such results seemed to indicate generally that the used potato cultivars differed in their chemical composition parameters. Concerning the starch content, Danilchenko et al., (2005) found that the cultivars used of potato differed in the content of starch.

The comparisons among the values of the chemical composition of potato leaves and tubers as affected by the organic manure rates were found to be significant in most cases, but with different magnitudes, in both growing seasons. The best treatment was that of organic manure at the rate of $15 \mathrm{~m}^{3}$. ha. ${ }^{-1}$, which gave the highest values for all the studied chemical compositions of leaves and tubers of potato, with the exception of total sugars in the first season (Table 5). The previous mentioned results were in general accordance with those reported by many researchers such as: Singh et al. (1996) for $\mathrm{N} \% \mathrm{P} \%$ and $\mathrm{K} \%$; Blecharezyk and Skrzyezak (1996) for $\mathrm{P} \%$ and $\mathrm{K} \%$; Arisha and Bardisi (1999) for starch and carbohydrates, who reported that using organic manure significantly increased the contents of leaves and tubers, in most cases, of potato plants.

The results in Table 5 observed generally that the effects of mineral NPK fertilizers levels on the chemical composition parameters appeared to be high enough to be significant, with only one exception, in both seasons. The application of the highest level of NPK fertilizer $\left(\mathrm{N}_{3} \mathrm{P}_{3} \mathrm{~K}_{3}\right)$ at the rate of 300-200-200 kg.ha. ${ }^{-1}$ gave significant highest value of $\mathrm{N} \%$, in the two years. Nevertheless, using the mineral NPK fertilizer at the rate of $200-150-150 \mathrm{~kg}^{-1}$. ${ }^{-1}$ reflected significant highest values of $\mathrm{P} \%, \mathrm{~K} \%$, starch, and carbohydrates, in the seasons of 2007 and 2008. These results seemed generally to cope with the findings of Adhikari and Sharma (2004) for N,P and K contents in leaves; who found that application of NPK fertilizer with high levels gave high concentration of these elements in potato leaves. Concerning the starch content, Tashkhodzhaev (1985), and Danilchenko et al., (2005) found that application of NPK fertilizers increased this component in potato tuber.

\section{First-order interactions:}

\section{Vegetative growth characters}

Results in Table 6 illustrated the effects of the firstorder interactions (cultivars $\mathrm{x}$ organic manure, cultivars $\mathrm{x}$ mineral NPK fertilizer, and organic manure $\mathrm{x}$ mineral NPK fertilizer) on vegetative growth characters of potato plants.

The effect of interactions between cultivars and organic manure on the characters plant height, number of aerial stems plant ${ }^{-1}$, foliage fresh weight plant $^{-1}$, and 
leaves dry matter content were found to be significant, in both winter seasons.

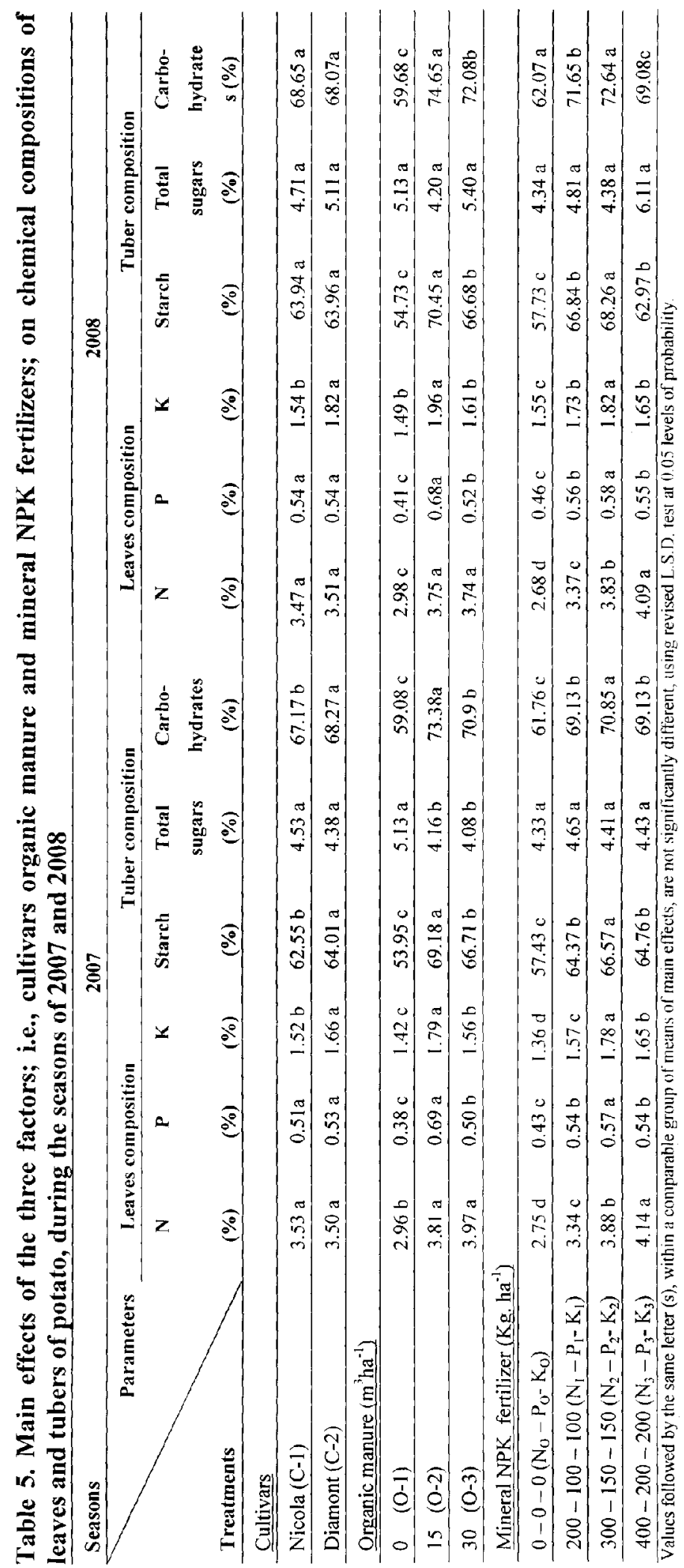




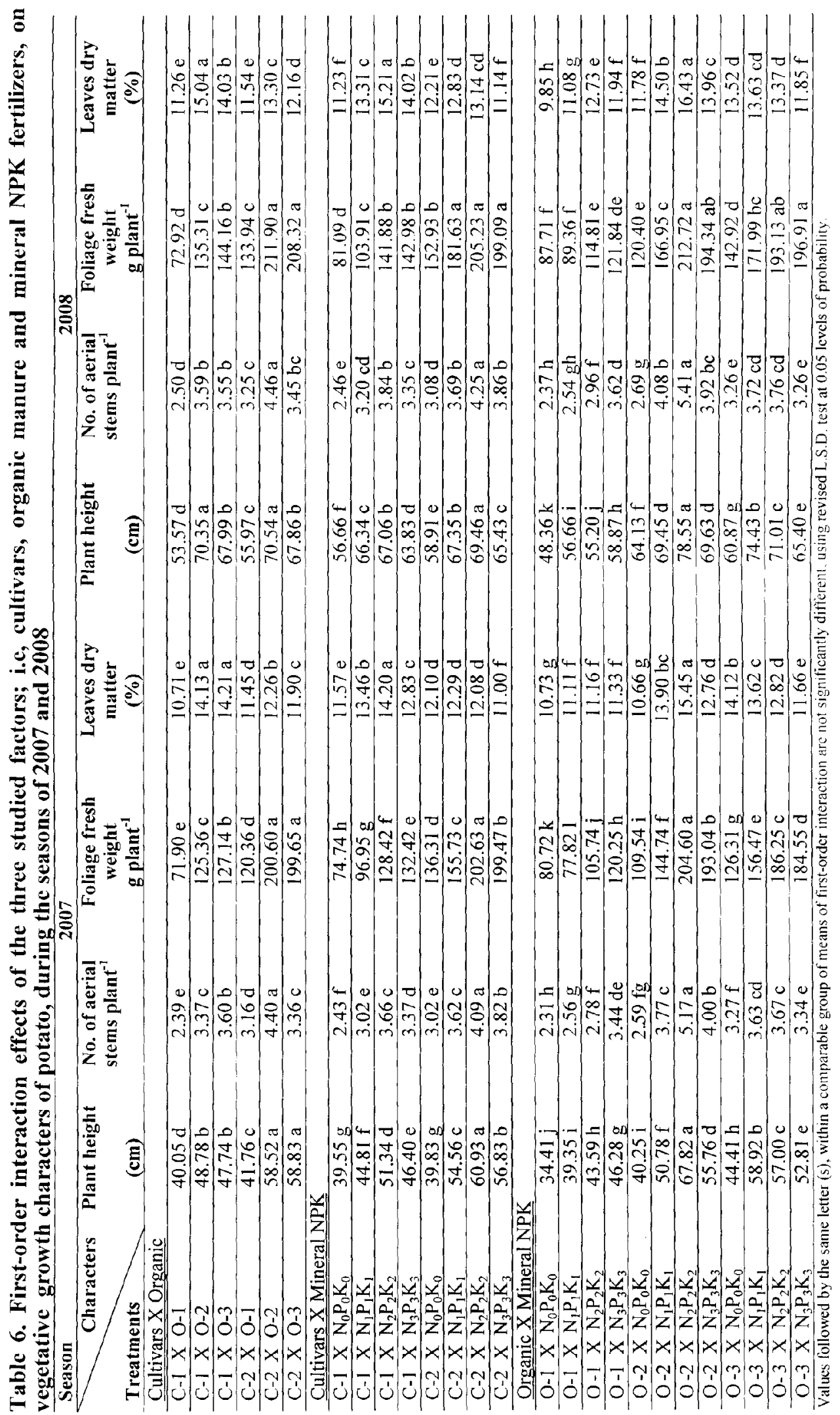


The combination between the cultivar Diamont and the application of organic manure at the rate of $15 \mathrm{~m}^{3} \mathrm{ha}^{-1}$ reflected the best interaction, which gave the significant highest mean values of all vegetative growth characters, with the exception of leaves dry matter content, in both years. Concerning leaves dry matter content, the results illustrated that the most favorable interactive effect for this parameter was the combination between cultivar Nicola and organic manure at the rate of $\left(5 \mathrm{~m}^{3} \mathrm{ha}^{-1}(\mathrm{C}-1\right.$ $\mathrm{x}$ O-2), in both seasons.

The presented results in Table 6 showed that using the cultivar Diamont combined with application of the third level of mineral NPK fertilizer at the rate of 300$150-150 \mathrm{~kg}$ ha. $^{-1}\left(\mathrm{C}-2 \times \mathrm{N}_{2} \mathrm{P}_{2} \mathrm{~K}_{2}\right)$ gave the significant highest mean values of the characters plant height, number of aerial stems plant ${ }^{-1}$ and foliage fresh weight plant $^{1}$, in both growing seasons. This result seemed to agree with the finding of Shafeek et al. (2001), who found that the potato cultivars significantly differed in vegetative growth characters as affected by mineral NPK fertilizers. The comparisons among the mean values of the dry matter content reflected that the best treatment combination between cultivars and mineral NPK fertilizer was given by the combination between cultivar Nicola and the application of mineral NPK fertilizer at the rate of 300-150-150 kg ha. ${ }^{-1}$

Regarding the first order interaction effects between organic manure and mineral NPK fertilizer, the results reflected generally that the comparisons among the mean values for the vegetative growth characters as affected by these two factors appeared to be significant, but with different magnitudes, in the two growing seasons. The obtained results illustrated that organic manure application at the rate of $15 \mathrm{~m}^{3}$ ha. ${ }^{-1}$ combined with using the mineral NPK fertilizer at the rate of 300$150-150 \mathrm{~kg} \mathrm{ha}^{-1}$ reflected the best interaction treatment, since it gave the highest mean values for all the studied vegetative growth characters, in both seasons. These results reflected such coping with those obtained by Ashour and Sarhan (1998) and Shafeek et al. (2001), who stated that the combination between organic manure and mineral NPK gave the highest mean values of vegetative growth characters of potato plants. On the other hand, the lowest mean values for the vegetative growth characters was given by the control treatment (without application) either of organic manure or mineral NPK fertilizer $\left(\mathrm{O}_{1} \times \mathrm{P}_{0} \mathrm{P}_{0} \mathrm{~K}_{0}\right)$, in the two years.

\section{Yield and its components characters:}

Results in Table 7 illustrated the first-order interaction effects; i.e., cultivars $\mathrm{x}$ organic manure, cultivars $\mathrm{x}$ mineral NPK fertilizers and organic manure $\mathrm{x}$ mineral NPK fertilizers; on the yield and its components characters, during the two growing seasons of 2007 and 2008.

Concerning the effects of the interaction between cultivars and organic manure rates, the results reflected generally that the comparisons among the mean values of the characters tuber fresh weight, number of tubers plant $^{-1}$, tubers weight plant $^{-1}$ and tuber dry matter content were found to be significant, in both seasons. The obtained results showed that using the cultivar Diamont combined with the application of organic manure at the rate of $15 \mathrm{~m}^{3} \mathrm{ha}^{-1}$ gave the most favorable interaction effect, which showed the significant highest mean values for all the studied yield and its component characters, in both years. The previous mentioned results could the explained, generally, on the basis of the used cultivars Nicola and Diamont reflected high response to using organic manure on the yield and its component characters. In this respect, Ashour and Sarhan (1998) found that using different rates of organic manure with different potato cultivars increased yield characters. Also, farmyard manure has a considerable effect on increasing the average tuber weight (Karmanov and Gushchiva, 1986); tuber yield (Saghin, 1989; Sood et al., 1994; Reche et al., 1997). However, further increase of farmyard manure was not effective on average tuber weight and tuber yield (Karmanov and Gushchiva, 1986) of potato plants.

Pertaining the interaction effects of the two cultivars and the four levels of mineral NPK fertilizers on the yield and its components characters, the results in Table 7 exhibited significant differences, within each studied character, in both seasons. Comparisons among the mean values of the different treatment combinations indicated that values of all the studied yield and its components parameters for the combination between cultivar Diamont and application of mineral NPK fertilizer at the rate of 300-150-150 kg ha. ${ }^{-1}$ were significantly higher, than those of all other treatment combinations, in both growing seasons. Such results generally reflected agreement with those reported by Shafeek etal. (2001), who found that potato cultivars differed in their responses to application of mineral NPK for the yield and its components characters. Also, the same authors found that increasing the mineral NPK fertilizer resulted in the high values of some yield and its components characters of potato.

The effects of interactions between the different rates of organic manure and mineral NPK fertilizer on the studied yield and its components characters of potato plants were found to be significant, in the two seasons, as shown in Table 7. The application of organic manure at the rate of $15 \mathrm{~m}^{3} \mathrm{ha}^{-1}$ combined with 
the application of mineral NPK fertilizer at the rate of $\quad 300-150-150 \mathrm{~kg} \mathrm{ha}{ }^{1}$

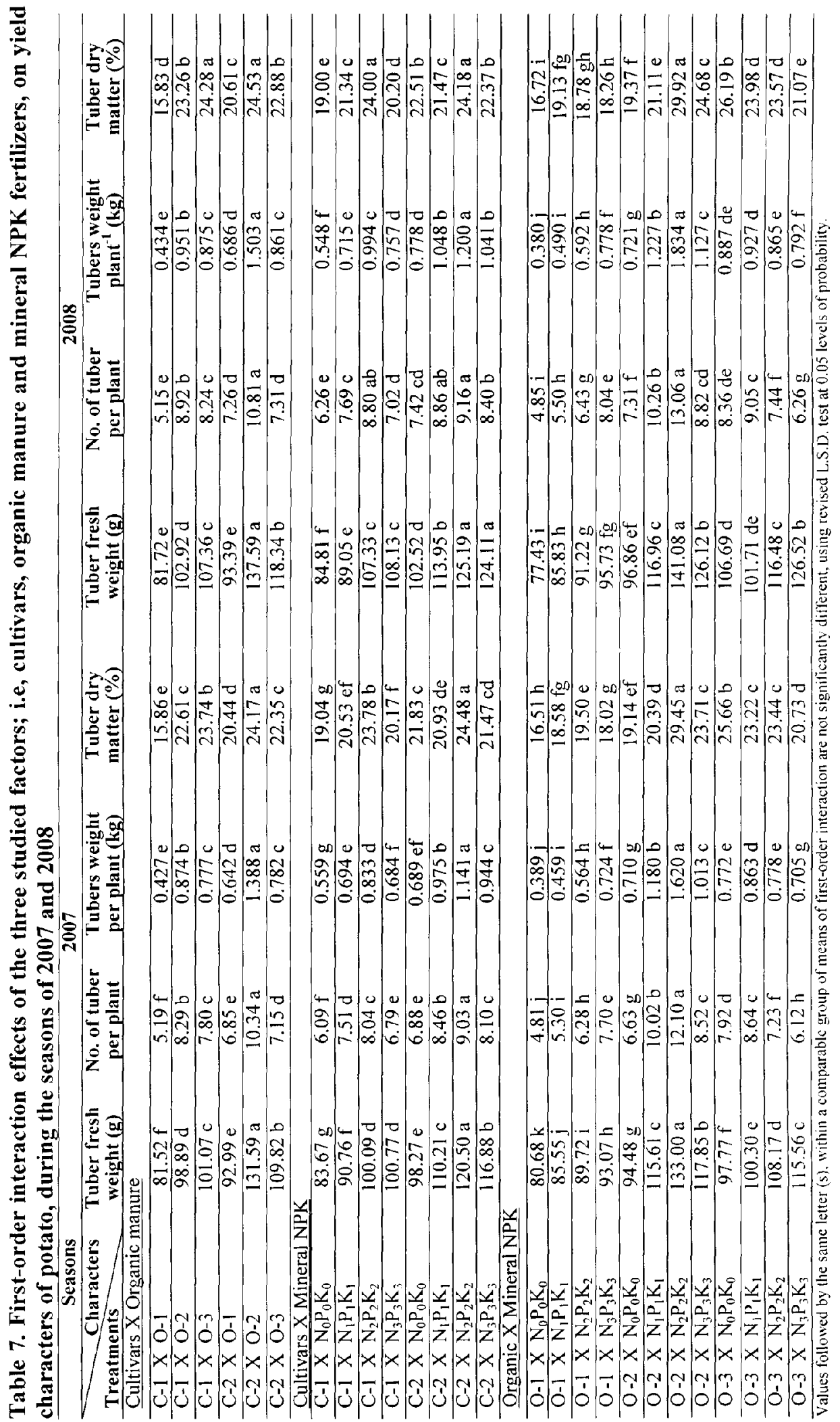


resulted in the significant highest mean values for the characters tuber fresh weight plant ${ }^{-1}$, number of tubers plant $^{-1}$, tubers weight plant $^{-1}$ and tuber dry matter contents, in the seasons of 2007 and 2008. The mentioned results concerning the yield and its components characters were in general accordance with those reported by many investigators such as Efremov and Samoilov (1985); Anomika and Singh (1996), and Ashour and Sarhan (1998) for tuber yield; Spoil and Fedotova (1987) for tuber weight; Borin and Magrini (1987) for number of tubers plant ${ }^{-1}$ since, they found that combination between NPK and organic manure were found to be more effective in their studied characters of potato.

\section{Chemical composition parameters:}

The results of the first-order interaction effects of cultivars, organic manure and mineral NPK fertilizer on the chemical composition of leaves and tubers of potatoes plants, during the seasons of 2007 and 2008 are shown in Table 8.

Concerning the interaction effects between the cultivars and organic manure rates on chemical compositions, the results reflected generally that the differences among the mean values of each studied parameter were found to be significant, in most cases, but with different magnitudes, in both seasons. The obtained results indicated that the highest values of $\mathrm{N} \%$, $\mathrm{P} \%$, starch and carbohydrates contents, in both seasons, were given by the combination between cultivar Nicola and application of organic manure at the rate of $15 \mathrm{~m}^{3}$. ha. ${ }^{-1}$. Whereas, using the cultivar Diamont without addition organic manure gave the highest value of sugars content, in the two seasons. The combination between cultivar Diamont and application of organic manure at the rate of $15 \mathrm{~m}^{3}$. ha. ${ }^{-1}$ reflected the highest value of $\mathrm{K} \%$, in both seasons. Generally, the obtained results seemed to agree with those obtained by Striban et al., (1984) and Makaraviciute (2003) for carbohydrates; Singh et al., (1996) for N, P and K percentages; and El-Sirafy et al., (2008) for starch content, who found that organic manure application to the potato plants increased the chemical compositions in their studies characters.

Regarding the interaction effects between cultivars and mineral NPK fertilizer on the chemical composition parameters, the results reflected generally that the differences among values of the studied parameters were high enough to be significant, in most cases, in the two growing seasons. The highest values of the parameters $\mathrm{N} \%, \mathrm{P} \%, \mathrm{~K} \%$, starch and carbohydrates contents were given by the combination between the cultivar Diamont combined with application of mineral
NPK fertilizer at the rate of $300-150-150 \mathrm{~kg} \mathrm{ha}^{-1}$, in both seasons. These results indicated generally that the two cultivars reflected different responses to application of mineral NPK fertilizers for the chemical composition parameters. Adhikari and Sharma (2004) found that application of mineral NPK fertilizer with increasing level resulted in increasing in $\mathrm{N}, \mathrm{P}$ and $\mathrm{K}$ contents of potato leaves. The results illustrated also that the lowest value of sugars content was given by using the cultivar Diamont without application of mineral NPK fertilizer (control), in the two years.

As for the interaction effects between organic manure rates and mineral NPK fertilizer levels on the chemical composition of leaves and tubers, the obtained results indicated that the treatment combination between application of organic manure at the rate of $15 \mathrm{~m}^{3} \mathrm{ha}^{-1}$ combined with the application of mineral NPK at the rate of 300-150-150 $\mathrm{kg} \mathrm{ha}^{-1}$, gave the highest values of all the studied chemical composition parameters, with only one exception. This exception was the total sugars parameter, which reflected the best (lowest value) combination between the previously mentioned interaction treatments. Such results seemed to agree with the finding of Abou-El-Salehein et al. (1994), who found that the combination between potassium fertilizer and organic manure gave increasing effects on starch, carbohydrates and total sugars contents.

\section{Second-order interaction effects:}

The results presented in Tables 9, 10 and 11 illustrated the effects of the second-order interactions among cultivars, organic manure rates and mineral NPK levels on vegetative growth, yield and its components, and chemical composition of leaves and tubers of potato plants in the seasons of 2007 and 2008.

\section{Vegetative growth characters:}

Table 9 showed that the comparisons among the mean values of all the treatment combinations for the plant height, number of aerial stems plant ${ }^{-1}$, foliage fresh weight plant $^{-1}$ and leaves dry matter content characters were high enough to be significant, in most cases, but with different magnitudes, in the two seasons. Such results generally indicated that the studied cultivars of potato reflected high responses, but with different degree, to the application of both fertilizers organic manure and mineral NPK. Since, the combinations among the three studied factors reflected positive effects on most studied vegetative growth characters. Also, it is well known that good cultivars are essential for the production of a satisfactory crop of vegetables for both growers and consumers. In addition, the fertilizers either of organic and/or inorganic are essential for plant growth and yield. 


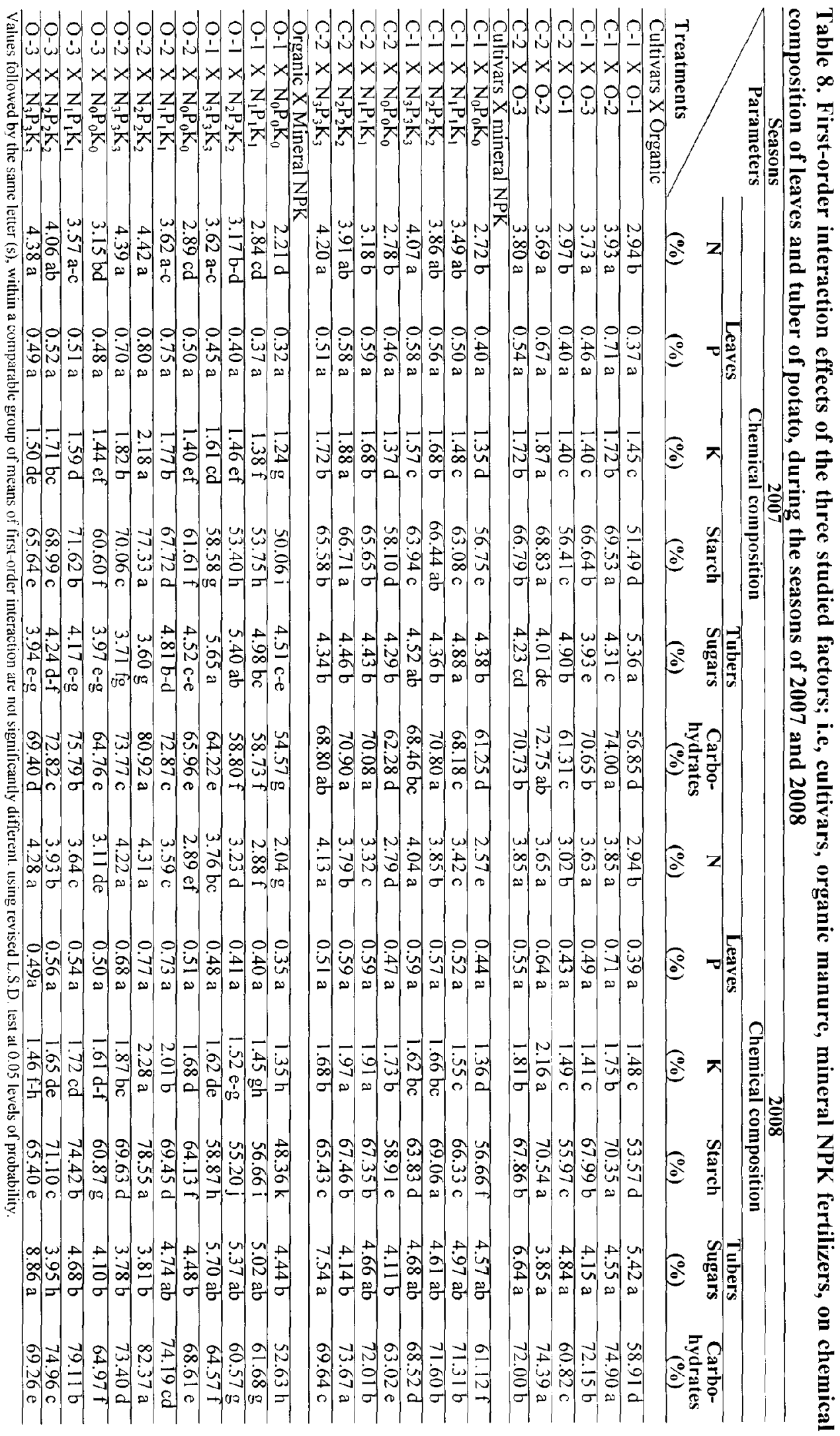


Table 9. Second- order interaction effects among the three factors, i.e., cultivars, organic manure and mineral NPK; on vegetative growth characters of potato, during the seasons of 2007 and 2008

\begin{tabular}{|c|c|c|c|c|c|c|c|c|}
\hline Seasons & \multicolumn{4}{|c|}{2007} & \multicolumn{4}{|c|}{2008} \\
\hline Characters & $\begin{array}{c}\text { Plant } \\
\text { height } \\
(\mathrm{cm})\end{array}$ & $\begin{array}{c}\text { No. of } \\
\text { aerial } \\
\text { stems } \\
\text { plant }^{-1}\end{array}$ & $\begin{array}{c}\text { Foliage } \\
\text { fresh } \\
\text { weight } \\
\text { (g/plant) }\end{array}$ & $\begin{array}{c}\text { Leaves } \\
\text { dry } \\
\text { matter } \\
(\%)\end{array}$ & $\begin{array}{c}\text { Plant } \\
\text { height } \\
(\mathrm{cm})\end{array}$ & $\begin{array}{l}\text { No. of } \\
\text { aerial } \\
\text { stems } \\
\text { plant }^{-1}\end{array}$ & $\begin{array}{c}\text { Foliage } \\
\text { fresh } \\
\text { weight } \\
\text { (g/plant) }\end{array}$ & $\begin{array}{c}\text { Leaves } \\
\text { dry } \\
\text { matter } \\
(\%)\end{array}$ \\
\hline \multicolumn{9}{|c|}{ Cultivars X organic X mineral NPK } \\
\hline C-1 X 0-1 X N $\mathrm{P}_{0} \mathrm{~K}_{0}$ & $35.16 \mathrm{o}$ & $2.00 \mathrm{~m}$ & $63.54 \mathrm{~s}$ & $9.35 \mathrm{j}$ & $47.20 \mathrm{o}$ & 1.991 & $61.68 \mathrm{i}$ & $8.60 \mathrm{i}$ \\
\hline $\mathrm{C}-1 \mathrm{X} 0-1 \mathrm{X} \mathrm{N}_{0} \mathrm{P}_{1} \mathrm{~K}_{1}$ & $38.57 \mathrm{n}$ & 2.321 & $68.69 \mathrm{r}$ & $10.21 \mathrm{hi}$ & $53.92 \mathrm{~m}$ & 2.171 & $69.90 \mathrm{i}$ & $9.86 \mathrm{~h}$ \\
\hline $\mathrm{C}-1 \mathrm{X} \mathrm{0-1} \mathrm{X} \mathrm{N}_{0} \mathrm{P}_{2} \mathrm{~K}_{2}$ & 42.201 & $2.42 \mathrm{kl}$ & $75.69 \mathrm{~g}$ & $11.15 \mathrm{~g}$ & $55.53 \mathrm{~m}$ & $2.72 \mathrm{k}$ & $79.19 \mathrm{i}$ & $12.80 \mathrm{ef}$ \\
\hline $\mathrm{C}-1 \mathrm{X} 0-1 \mathrm{X} \mathrm{N}_{0} \mathrm{P}_{3} \mathrm{~K}_{3}$ & $44.27 \mathrm{i}-\mathrm{k}$ & $2.81 \mathrm{ij}$ & $79.71 \mathrm{~g}$ & $12.14 \mathrm{f}$ & 57.621 & $3.13 \mathrm{ij}$ & $82.91 \mathrm{hi}$ & $13.79 \mathrm{~d}$ \\
\hline $\mathrm{C}-1 \mathrm{X} 0-2 \mathrm{X} \mathrm{N}_{0} \mathrm{P}_{0} \mathrm{~K}_{0}$ & $40.21 \mathrm{mn}$ & $2.01 \mathrm{~m}$ & $68.76 \mathrm{r}$ & $11.45 \mathrm{~g}$ & $63.57 \mathrm{ij}$ & 2.211 & $71.34 \mathrm{i}$ & $12.75 \mathrm{ef}$ \\
\hline C-1 X 0-2 X N $\mathrm{N}_{0} \mathrm{P}_{1}$ & $45.25 \mathrm{ij}$ & $3.11 \mathrm{~h}$ & $99.34 \mathrm{~m}$ & $15.00 \mathrm{~b}$ & $70.21 \mathrm{ef}$ & $3.73 \mathrm{ef}$ & $111.71 \mathrm{~g}$ & $15.56 \mathrm{~b}$ \\
\hline C-1 X 0-2 X N $\mathrm{N}_{0} \mathrm{P}_{2} \mathrm{~K}_{2}$ & $58.48 \mathrm{~d}$ & $4.71 \mathrm{~b}$ & $167.72 \mathrm{f}$ & $16.95 \mathrm{a}$ & $79.28 \mathrm{a}$ & $4.90 \mathrm{~b}$ & $185.37 \mathrm{~cd}$ & $17.19 \mathrm{a}$ \\
\hline $\mathrm{C}-1 \mathrm{X} 0-2 \mathrm{X} \mathrm{N}_{0} \mathrm{P}_{3} \mathrm{~K}_{3}$ & $51.19 \mathrm{~g}$ & $3.65 \mathrm{ef}$ & $165.61 \mathrm{~g}$ & $13.21 \mathrm{e}$ & $68.31 \mathrm{~g}$ & $3.52 \mathrm{f}-\mathrm{h}$ & $172.81 \mathrm{de}$ & $14.65 \mathrm{c}$ \\
\hline $\mathrm{C}-1 \mathrm{X} 0-3 \mathrm{X} \mathrm{N}_{0} \mathrm{P}_{0} \mathrm{~K}_{0}$ & $43.28 \mathrm{kl}$ & $3.27 \mathrm{gh}$ & $91.92 \mathrm{n}$ & $14.02 \mathrm{~d}$ & $59.18 \mathrm{kl}$ & $3.19 \mathrm{~h}-\mathrm{j}$ & $110.25 \mathrm{gh}$ & $12.34 \mathrm{f}$ \\
\hline $\mathrm{C}-1 \mathrm{X} 0-3 \mathrm{X} \mathrm{N}_{0} \mathrm{P}_{1} \mathrm{~K}_{1}$ & $50.62 \mathrm{~g}$ & $3.64 \mathrm{ef}$ & 122.831 & $15.17 \mathrm{~b}$ & $74.89 \mathrm{~b}$ & $3.70 \mathrm{ef}$ & $132.11 \mathrm{fg}$ & $14.51 \mathrm{c}$ \\
\hline $\mathrm{C}-1 \mathrm{X} 0-3 \mathrm{X} \mathrm{N}_{0} \mathrm{P}_{2} \mathrm{~K}_{2}$ & $53.33 \mathrm{f}$ & $3.85 \mathrm{de}$ & $141.87 \mathrm{j}$ & $14.51 \mathrm{c}$ & $72.34 \mathrm{~cd}$ & $3.91 \mathrm{de}$ & $161.07 \mathrm{de}$ & $15.64 \mathrm{~b}$ \\
\hline $\mathrm{C}-1 \times 0-3 \times \mathrm{N}_{0} \mathrm{P}_{3} \mathrm{~K}_{3}$ & $43.74 \mathrm{i}-1$ & 3.65 ef & $151.94 \mathrm{i}$ & $13.15 \mathrm{e}$ & $65.58 \mathrm{~h}$ & $3.39 \mathrm{f}-\mathrm{i}$ & $173.21 \mathrm{de}$ & $13.64 \mathrm{~d}$ \\
\hline $\mathrm{C}-2 \mathrm{X} 0-1 \mathrm{X} \mathrm{N}_{0} \mathrm{P}_{0} \mathrm{~K}_{0}$ & $33.65 \mathrm{o}$ & $2.62 \mathrm{jk}$ & $97.90 \mathrm{~m}$ & $12.11 \mathrm{f}$ & $49.51 \mathrm{n}$ & $2.75 \mathrm{k}$ & $113.74 \mathrm{~g}$ & $11.10 \mathrm{~g}$ \\
\hline C-2 X 0-1 X N $\mathrm{N}_{0} \mathrm{P}_{1}$ & $40.14 \mathrm{mn}$ & $2.79 \mathrm{ij}$ & 86.96 o & $12.01 \mathrm{f}$ & $59.40 \mathrm{k}$ & $2.91 \mathrm{jk}$ & $110.82 \mathrm{gh}$ & $12.29 \mathrm{f}$ \\
\hline $\mathrm{C}-2 \mathrm{X} 0-1 \mathrm{X} \mathrm{N}_{0} \mathrm{P}_{2} \mathrm{~K}_{2}$ & $44.98 \mathrm{ij}$ & $3.15 \mathrm{~h}$ & $135.79 \mathrm{k}$ & $11.17 \mathrm{~g}$ & $54.86 \mathrm{~m}$ & $3.21 \mathrm{~h}-\mathrm{i}$ & 150.44 ef & $12.66 \mathrm{f}$ \\
\hline $\mathrm{C}-2 \mathrm{X} 0-1 \mathrm{X} \mathrm{N}_{0} \mathrm{P}_{3} \mathrm{~K}_{3}$ & $48.29 \mathrm{~h}$ & $4.07 \mathrm{~d}$ & $160.79 \mathrm{~h}$ & $10.52 \mathrm{~h}$ & $60.12 \mathrm{k}$ & $4.12 \mathrm{~cd}$ & $160.77 \mathrm{de}$ & $10.10 \mathrm{~g}$ \\
\hline $\mathrm{C}-2 \times 0-2 \mathrm{X} \mathrm{N}_{0} \mathrm{P}_{0} \mathrm{~K}_{0}$ & $40.29 \mathrm{~m}$ & $3.17 \mathrm{~h}$ & $150.32 \mathrm{i}$ & $9.97 \mathrm{i}$ & $64.67 \mathrm{hi}$ & $3.17 \mathrm{~h}-\mathrm{j}$ & $169.47 \mathrm{de}$ & $10.82 \mathrm{~g}$ \\
\hline $\mathrm{C}-2 \mathrm{X} 0-2 \mathrm{X} \mathrm{N}_{0} \mathrm{P}_{1} \mathrm{~K}_{1}$ & $56.32 \mathrm{e}$ & $4.42 \mathrm{c}$ & $190.13 \mathrm{e}$ & $12.80 \mathrm{e}$ & $68.69 \mathrm{fg}$ & $4.43 \mathrm{c}$ & $222.20 \mathrm{ab}$ & $13.45 \mathrm{~d}$ \\
\hline $\mathrm{C}-2 \mathrm{X} 0-2 \mathrm{X} \mathrm{N}_{0} \mathrm{P}_{2} \mathrm{~K}_{2}$ & $77.15 \mathrm{a}$ & $5.64 \mathrm{a}$ & $241.48 \mathrm{a}$ & $13.95 \mathrm{~d}$ & $79.83 \mathrm{a}$ & $5.93 \mathrm{a}$ & $240.07 \mathrm{a}$ & $15.67 \mathrm{~b}$ \\
\hline $\mathrm{C}-2 \mathrm{X} 0-2 \mathrm{X} \mathrm{N}_{0} \mathrm{P}_{3} \mathrm{~K}_{3}$ & $60.34 \mathrm{c}$ & $4.36 \mathrm{c}$ & $220.47 \mathrm{c}$ & $12.31 \mathrm{f}$ & $70.95 \mathrm{de}$ & $4.33 \mathrm{c}$ & $215.87 \mathrm{ab}$ & $13.27 \mathrm{de}$ \\
\hline $\mathrm{C}-2 \times 0-3 \mathrm{X} \mathrm{N}_{0} \mathrm{P}_{0} \mathrm{~K}_{0}$ & $45.54 \mathrm{j}$ & $3.28 \mathrm{gh}$ & $160.71 \mathrm{~h}$ & $14.22 \mathrm{~cd}$ & $62.56 \mathrm{j}$ & $3.33 \mathrm{~g}-\mathrm{i}$ & $175.59 \mathrm{de}$ & $14.71 \mathrm{c}$ \\
\hline $\mathrm{C}-2 \times 0-3 \times \mathrm{N}_{0} \mathrm{P}_{1} \mathrm{~K}_{1}$ & $67.23 \mathrm{~b}$ & $3.62 \mathrm{ef}$ & $190.11 \mathrm{e}$ & $12.07 \mathrm{f}$ & $73.98 \mathrm{bc}$ & 3.73 ef & $211.88 \mathrm{bc}$ & $12.76 \mathrm{ef}$ \\
\hline $\mathrm{C}-2 \times 0-3 \mathrm{X} \mathrm{N}_{0} \mathrm{P}_{2} \mathrm{~K}_{2}$ & $60.67 \mathrm{c}$ & $3.48 \mathrm{fg}$ & $230.64 \mathrm{~b}$ & $11.14 \mathrm{~g}$ & $69.69 \mathrm{e}-\mathrm{g}$ & $3.61 \mathrm{e}-\mathrm{g}$ & $225.18 \mathrm{ab}$ & $11.10 \mathrm{~g}$ \\
\hline $\mathrm{C}-2 \mathrm{X} 0-3 \mathrm{X} \mathrm{N}_{0} \mathrm{P}_{3} \mathrm{~K}_{3}$ & $61.87 \mathrm{c}$ & $3.03 \mathrm{hi}$ & $217.17 \mathrm{~d}$ & $10.17 \mathrm{hi}$ & $65.23 \mathrm{hi}$ & $3.13 \mathrm{ij}$ & $220.62 \mathrm{ab}$ & $10.00 \mathrm{~h}$ \\
\hline
\end{tabular}

Values followed by the same letter (s), within a comparable group of means of the second -order interaction effects, are not significantly different, using revised L.S.D.test at 0.05 level.

'The best interaction treatment combination was achieved by the combination among the cultivar Diamont combined with application of organic manure at the rate of $15 \mathrm{~m}^{3} \mathrm{ha}^{-1}$ and the application of mineral NPK fertilizer at the rate of 300-150-150 kg ha. ${ }^{-1}$, which resulted in the highest mean values of the characters plant height, number of aerial stems plant ${ }^{-1}$, and foliage fresh weight plant $^{-1}$, in the two experimental seasons. In this respect, Ashour and Sarhan (1998) found that addition of organic manure combined with mineral NPK fertilizers gave the highest values of vegetative growth characters of potato. Also, Awad (2005) found similar finding concerning the effects of organic and inorganic fertilizers on vegetative growth characters of potato plants. Concerning the leaves dry matter content parameter, the results, in both seasons, indicated that the best interaction treatment was given by the combinations among cultivar Nicola and application of organic manure at the rate of $15 \mathrm{~m}^{3} \mathrm{ha}^{-1}$ combined with application of mineral NPK fertilizer at the rate of 300150-150 kg ha. ${ }^{-1}$, which reflected the highest mean value of this parameter.

\section{Yield and its components characters:}

Concerning the second-order interaction effects among the two potato cultivars, three organic manure rates and four mineral NPK fertilizer levels on yield and its components characters, the comparisons among the mean values of each studied character appeared to be significant, during both seasons (Table10). The obtained results indicated that the most favorable interaction effect was given by the combinations among the cultivar Diamont combined with the application of organic manure at the rate of $15 \mathrm{~m}^{3} \mathrm{ha}^{-1}$ and using the mineral NPK fertilizer at the rate of $300-150-150 \mathrm{~kg}$ ha. ${ }^{-1}$, 
Table 10. Second- order interaction effects among the three factors, i.e., cultivars, organic manure and mineral NPK; on yield characters of potato, during the seasons of 2007 and 2008

\begin{tabular}{|c|c|c|c|c|c|c|c|c|}
\hline Seasons & \multicolumn{4}{|c|}{2007} & \multicolumn{4}{|c|}{2008} \\
\hline Characters & $\begin{array}{c}\text { Tuber } \\
\text { fresh } \\
\text { weight } \\
\text { (g) }\end{array}$ & $\begin{array}{l}\text { No. of } \\
\text { tubers } \\
\text { plant }^{-1}\end{array}$ & $\begin{array}{c}\text { Tubers } \\
\text { weight } \\
\text { per plant } \\
(\mathrm{kg})\end{array}$ & $\begin{array}{c}\begin{array}{c}\text { Tuber } \\
\text { dry } \\
\text { matter }\end{array} \\
(\%)\end{array}$ & $\begin{array}{l}\text { Tuber } \\
\text { fresh } \\
\text { weight } \\
\text { (g) }\end{array}$ & $\begin{array}{l}\text { No. of } \\
\text { tubers } \\
\text { plant }^{-1}\end{array}$ & $\begin{array}{c}\text { Tubers } \\
\text { weight per } \\
\text { plant } \\
\text { (kg) }\end{array}$ & $\begin{array}{c}\text { Tuber } \\
\text { dry } \\
\text { matter } \\
(\%)\end{array}$ \\
\hline \multicolumn{9}{|c|}{ Cultivars X organic X mineral NPK } \\
\hline $\mathrm{C}-1 \mathrm{X} 0-1 \mathrm{X} \mathrm{N}_{0} \mathrm{P}_{0} \mathrm{~K}_{0}$ & $75.61 \mathrm{p}$ & 4.341 & $0.325 \mathrm{r}$ & $14.17 \mathrm{o}$ & $72.75 \mathrm{~m}$ & $3.92 \mathrm{k}$ & $0.285 \mathrm{~m}$ & $13.74 \mathrm{~m}$ \\
\hline $\mathrm{C}-1 \mathrm{X} 0-1 \mathrm{X} \mathrm{N}_{0} \mathrm{P}_{1} \mathrm{~K}_{1}$ & $80.88 \mathrm{n}$ & 4.471 & $0.367 q$ & $17.17 \mathrm{mn}$ & $81.70 \mathrm{kl}$ & $4.20 \mathrm{k}$ & 0.3701 & $18.15 \mathrm{j}$ \\
\hline $\mathrm{C}-1 \mathrm{X} 0-1 \mathrm{X} \mathrm{N}_{0} \mathrm{P}_{2} \mathrm{~K}_{2}$ & $83.81 \mathrm{~m}$ & $5.41 \mathrm{k}$ & $0.451 \mathrm{p}$ & $17.10 \mathrm{n}$ & $84.63 \mathrm{jk}$ & $5.66 \mathrm{j}$ & $0.479 \mathrm{k}$ & $16.67 \mathrm{k}$ \\
\hline $\mathrm{C}-1 \mathrm{X} 0-1 \mathrm{X} \mathrm{N}_{0} \mathrm{P}_{3} \mathrm{~K}_{3}$ & 85.771 & $6.54 \mathrm{i}$ & $0.566 \mathrm{~m}$ & $15.00 \mathrm{o}$ & $87.78 \mathrm{ik}$ & $6.84 \mathrm{hi}$ & $0.601 \mathrm{j}$ & 14.781 \\
\hline $\mathrm{C}-1 \mathrm{X} 0-2 \mathrm{X} \mathrm{N}_{0} \mathrm{P}_{0} \mathrm{~K}_{0}$ & $78.23 \mathrm{o}$ & $5.14 \mathrm{k}$ & 0.516 o & $19.11 \mathrm{jk}$ & 80.481 & $5.69 \mathrm{j}$ & $0.431 \mathrm{kl}$ & $19.03 \mathrm{i}$ \\
\hline $\mathrm{C}-1 \mathrm{X} 0-2 \mathrm{X} \mathrm{N}_{0} \mathrm{P}_{1} \mathrm{~K}_{1}$ & $95.90 \mathrm{j}$ & $8.95 \mathrm{~d}$ & $0.852 \mathrm{~g}$ & 2024 hi & $93.21 \mathrm{~h}$ & $9.11 \mathrm{c}-\mathrm{e}$ & $0.848 \mathrm{gh}$ & $21.11 \mathrm{fg}$ \\
\hline $\mathrm{C}-1 \times 0-2 \mathrm{X} \mathrm{N}_{0} \mathrm{P}_{2} \mathrm{~K}_{2}$ & $115.81 \mathrm{e}$ & $11.36 \mathrm{~b}$ & & & & $12.01 \mathrm{~b}$ & $1.646 \mathrm{~b}$ & $28.70 \mathrm{~b}$ \\
\hline $\mathrm{C}-1 \mathrm{X} 0-2 \mathrm{X} \mathrm{N}_{0} \mathrm{P}_{3} \mathrm{~K}_{3}$ & $105.61 \mathrm{~g}$ & $7.72 \mathrm{~g}$ & $0.813 \mathrm{i}$ & $22.14 \mathrm{f}$ & $111.48 \mathrm{e}$ & $7.89 \mathrm{fg}$ & $0.880 \mathrm{fg}$ & $23.16 \mathrm{e}$ \\
\hline $\mathrm{C}-1 \mathrm{X} 0-3 \mathrm{X} \mathrm{N}_{0} \mathrm{P}_{0} \mathrm{~K}_{0}$ & $97.19 \mathrm{i}$ & $8.61 \mathrm{e}$ & $0.834 \mathrm{~h}$ & $23.84 \mathrm{e}$ & $101.19 \mathrm{fg}$ & $9.18 \mathrm{~cd}$ & $0.929 \mathrm{ef}$ & $24.26 \mathrm{~d}$ \\
\hline $\mathrm{C}-1 \times 0-3 \mathrm{X} \mathrm{N}_{0} \mathrm{P}_{1} \mathrm{~K}_{1}$ & $95.52 \mathrm{j}$ & $9.12 \mathrm{~cd}$ & & & $92.25 \mathrm{~h}$ & $9.75 \mathrm{~cd}$ & 0.927 ef & $24.76 \mathrm{~d}$ \\
\hline $\mathrm{C}-1 \mathrm{X} 0-3 \mathrm{X} \mathrm{N}_{0} \mathrm{P}_{2} \mathrm{~K}_{2}$ & $100.66 \mathrm{~h}$ & $7.36 \mathrm{~h}$ & $0.735 \mathrm{j}$ & $25.28 \mathrm{~d}$ & $110.84 \mathrm{e}$ & $7.72 \mathrm{fg}$ & $0.856 \mathrm{~g}$ & $26.15 \mathrm{c}$ \\
\hline $\mathrm{C}-1 \times 0-3 \mathrm{X} \mathrm{N}_{0} \mathrm{P}_{3} \mathrm{~K}_{3}$ & $110.92 \mathrm{f}$ & $6.12 \mathrm{j}$ & 0.6761 & $23.37 \mathrm{e}$ & $125.14 \mathrm{~cd}$ & $6.32 \mathrm{ij}$ & $0.790 \mathrm{~h}$ & $22.97 \mathrm{e}$ \\
\hline $\mathrm{C}-2 \mathrm{X} 0-1 \mathrm{X} \mathrm{N}_{0} \mathrm{P}_{0} \mathrm{~K}_{0}$ & 85.741 & & & $18.86 \mathrm{kl}$ & $82.12 \mathrm{kl}$ & $5.79 \mathrm{j}$ & $0.475 \mathrm{k}$ & $19.71 \mathrm{hi}$ \\
\hline $\mathrm{C}-2 \mathrm{X} 0-1 \mathrm{X} \mathrm{N}_{0} \mathrm{P}_{1} \mathrm{~K}_{1}$ & $90.23 \mathrm{k}$ & $6.13 \mathrm{j}$ & $0.552 \mathrm{n}$ & $19.99 \mathrm{ij}$ & $89.96 \mathrm{hi}$ & $6.81 \mathrm{hi}$ & $0.611 \mathrm{j}$ & $20.11 \mathrm{~h}$ \\
\hline $\mathrm{C}-2 \mathrm{X} 0-1 \mathrm{X} \mathrm{N}_{0} \mathrm{P}_{2} \mathrm{~K}_{2}$ & $95.64 \mathrm{j}$ & $7.15 \mathrm{~h}$ & 0.6781 & $21.89 \mathrm{fg}$ & $97.81 \mathrm{~g}$ & $7.20 \mathrm{gh}$ & $0.705 \mathrm{i}$ & $20.89 \mathrm{~g}$ \\
\hline $\mathrm{C}-2 \mathrm{X} 0-1 \mathrm{X} \mathrm{N}_{0} \mathrm{P}_{3} \mathrm{~K}_{3}$ & $100.36 \mathrm{~h}$ & $8.86 \mathrm{de}$ & $0.883 \mathrm{f}$ & $21.04 \mathrm{gh}$ & $103.67 \mathrm{f}$ & $9.24 \mathrm{~cd}$ & $0.956 \mathrm{de}$ & $21.74 \mathrm{f}$ \\
\hline C- 2 X 0-2 $\mathrm{X} \mathrm{N}_{0} \mathrm{P}_{0} \mathrm{~K}_{0}$ & $110.73 \mathrm{f}$ & $8.13 \mathrm{f}$ & $0.904 \mathrm{e}$ & $19.17 \mathrm{jk}$ & $113.24 \mathrm{e}$ & $8.94 \mathrm{de}$ & $1.012 \mathrm{~d}$ & $19.71 \mathrm{hi}$ \\
\hline C- 2 X 0-2 $\mathrm{X} \mathrm{N}_{0} \mathrm{P}_{1} \mathrm{~K}_{1}$ & $135.32 \mathrm{~b}$ & $11.10 \mathrm{~b}$ & $1.509 \mathrm{~b}$ & $20.56 \mathrm{hi}$ & $140.71 \mathrm{~b}$ & $11.42 \mathrm{~b}$ & $1.606 \mathrm{~b}$ & $21.11 \mathrm{fg}$ \\
\hline $\mathrm{C}-2 \times 0-2 \mathrm{X} \mathrm{N}_{0} \mathrm{P}_{2} \mathrm{~K}_{2}$ & $150.20 \mathrm{a}$ & $12.84 \mathrm{a}$ & $1.926 \mathrm{a}$ & $29.94 \mathrm{a}$ & $155.63 \mathrm{a}$ & $13.12 \mathrm{a}$ & $2.022 \mathrm{a}$ & $30.13 \mathrm{a}$ \\
\hline $\mathrm{C}-2 \mathrm{X} 0-2 \mathrm{X} \mathrm{N}_{0} \mathrm{P}_{3} \mathrm{~K}_{3}$ & $130.10 \mathrm{c}$ & $9.31 \mathrm{c}$ & $1.213 \mathrm{~d}$ & $25.28 \mathrm{~d}$ & $140.77 \mathrm{~b}$ & $9.76 \mathrm{c}$ & $1.374 \mathrm{c}$ & $26.19 \mathrm{c}$ \\
\hline C-2 X 0-3 X N $\mathrm{N}_{0} \mathrm{P}_{0} \mathrm{~K}_{0}$ & $98.35 \mathrm{i}$ & $7.23 \mathrm{~h}$ & $0.710 \mathrm{k}$ & $27.48 \mathrm{c}$ & $112.19 \mathrm{e}$ & $7.54 \mathrm{f}-\mathrm{h}$ & $0.846 \mathrm{gh}$ & $28.13 \mathrm{~b}$ \\
\hline $\mathrm{C}-2 \times 0-3 \mathrm{X} \mathrm{N}_{0} \mathrm{P}_{1} \mathrm{~K}_{1}$ & $105.08 \mathrm{~g}$ & $8.17 \mathrm{f}$ & $0.864 \mathrm{~g}$ & $22.26 \mathrm{f}$ & $111.18 \mathrm{e}$ & 8.34 ef & 0.926 ef & $23.20 \mathrm{e}$ \\
\hline $\mathrm{C}-2 \mathrm{X} 0-3 \mathrm{X} \mathrm{N}_{0} \mathrm{P}_{2} \mathrm{~K}_{2}$ & $115.68 \mathrm{e}$ & $7.11 \mathrm{~h}$ & $0.821 \mathrm{i}$ & $21.60 \mathrm{fg}$ & $122.11 \mathrm{~d}$ & $7.16 \mathrm{gh}$ & $0.874 \mathrm{fg}$ & $21.00 \mathrm{fg}$ \\
\hline $\mathrm{C}-2 \times 0-3 \mathrm{X} \mathrm{N}_{0} \mathrm{P}_{3} \mathrm{~K}_{3}$ & $120.19 \mathrm{~d}$ & $6.12 \mathrm{j}$ & $0.734 \mathrm{j}$ & $18.08 \mathrm{~lm}$ & $127.89 \mathrm{c}$ & $6.20 \mathrm{ij}$ & $0.793 \mathrm{~h}$ & $19.18 \mathrm{i}$ \\
\hline
\end{tabular}

Values followed by the same letter (s), within a comparable group of means of the second -order interaction effects, are not significantly different, using revised L.S.D. test at 0.05 level.

during both seasons. This favorable interaction effect gave the highest mean values of all the studied yield and its components. Similarly, Singh and Kushwah (2006) and Alam et al., (2007) showed that application of organic manure combined with mineral NPK fertilizers increased yield and its components characters of potato.

\section{Chemical composition parameters :}

The presented results in Table 11 illustrated the effects of the second-order interaction among the different studied factors on the chemical composition parameters of potato leaves and tubers. The results reflected generally that the differences among the values of all the studied parameters appeared to be significant, but with different magnitudes, with the exception of $\mathrm{P} \%$ value, which appeared to be insignificant, during the two growing seasons. The results reflected generally that using each cultivar and application of organic manure at the rate of 15 or $30 \mathrm{~m}^{3}$. $\mathrm{ha}^{-1}$ combined with increasing the application of mineral NPK fertilizer gave higher values of $\mathrm{N} \%$ and $\mathrm{K} \%$, in both seasons.

Results in Table 11 showed the interaction effects among the three studied factors on the chemical composition of tubers quality parameter starch, sugars and carbohydrates, in both growing seasons. The results reflected generally that the comparisons among the values of each studied parameter were significant, but with different magnitudes. The highest value of each of starch \% and carbohydrates $\%$ was given by the interaction among the cultivar Nicola combined with the application of organic mature at the rate of $15 \mathrm{~m}^{3}$ ha. ${ }^{-1}$ 


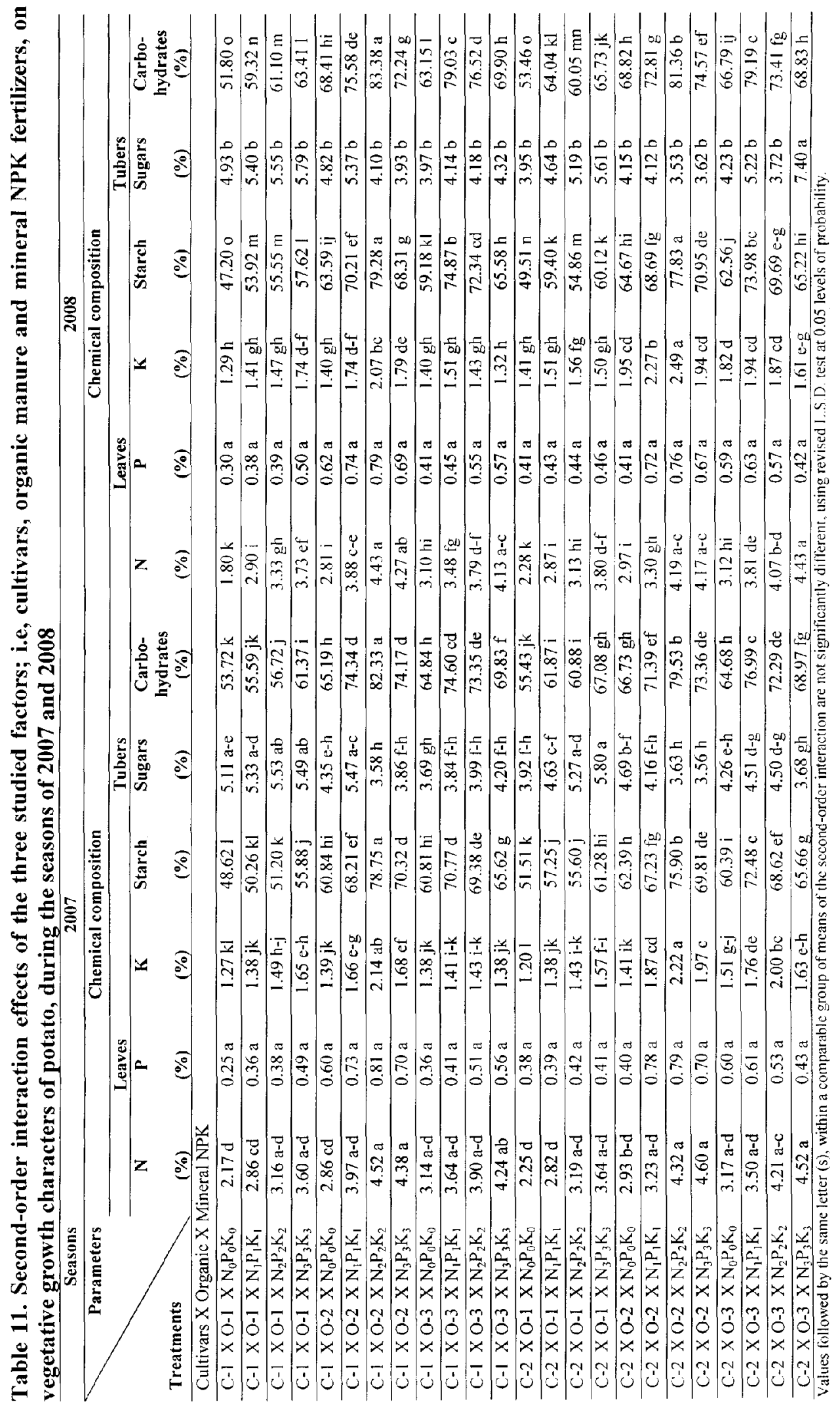


and application of mineral NPK fertilizer at the rate of $300-150-150 \mathrm{~kg} \mathrm{ha}^{-1}$, in the two growing seasons. Concerning the sugars content, the best interaction effect that gave the lowest value of this parameter was the combination among cultivar Diamont and application of organic manure at the rate of $15 \mathrm{~m}^{3} \mathrm{ha}^{-1}$ combined with the mineral NPK fertilizer at the rate of 400-200-200 kg ha- ${ }^{-1}$, during the two seasons. Such results seemed, generally, to agree with those obtained by Danilchenko et al. (2005) for starch; Shafeek et al. (2001) for N, P and K contents, who found that cultivars of potato, organic manure and mineral fertilizers in their combinations reflected positive effects on the studied chemical compositions of leaves and tubers of potato.

\section{REFERENCES}

Abou El-Salehein, E.H.; M.A. Ahamed and W.A. Fekry .1994. Effect of organic and inorganic fertilizers on growth, yield and quality of potato. Egypt. J. Appl. Sci. 14 (1):257-276.

Adhikari, R.C. and M.D. Sharma. 2004. Use of chemical fertilizers on potatoes in sandy loam soil under humid subtropical condition of Chitwan-Nepal Agric. Res. J. 5: 2326.

Alam, M.N.; M.S. Jahan; M.K. Ali; M. A. Ashraf and M.K. Islam. 2007. Effect of vermicompost and chemical fertilizers on growth, yield components of potato in Barind soil of Bangladesh. Journal of Applied Sciences Research. 3 (12): 1879-1888.

Al-Solaimani, S. G.; F. S. El-Nakhlawy and G. M. Basahui. 2009. Effect of irrigation water salinity, irrigation interval and sulphur fertilizer rates on forage yield, yield components and quality of blue panic grass (Panicum antictotale, L) Faculty of Metreology , Environment and Arid Land Agriculture, King Abdulaziz University, Jeddah, Saudi Arabia. 20: 113-135.

Anomika and R. Singh. 1996. Effect of planting dates and fertilizers on the crop raised from sprouts and seed tubers. Indian Potato Assoc. 23 (1-2): 81-84.

Arisha, H.M. and A. Bardisi. 1999. Effect of mineral and organic fertilizer on growth, yield and tuber quality of potato under sandy soil conditions. Zagazig J. Agric. Res. 20 (2): 391-405.

Ashour, S.A. and S.H. Sarhan. 1998. Effect of organic and inorganic fertilizers on growth yield and tuber quality of potato (Solanum tuberosum, L.). J. Agric. Sci. Mansoura Univ. 23 (7): 3359-3368.

Association of Official Analytical Chemists (AOAC).1995.Official methods of analysis,, $15^{\text {th }}$ ed. AOAC. International, Arlington, Verginia ,USA(1995).

Awad, E.M.; E.A. Tastoura; H.M. El-Foly and A.AbdelFattah. 2002. Response of potato growth, yield and quality to farmyard manure, sulphur and gypsum levels application. $2^{\text {nd }}$ International Conference of Horticulture
Science. 10-12 Sept. Agric. Kafr El Sheikh Tanta Univ. Egypt.

Blecharczyk, A. and G. Skrzyczak. 1996. The effect of long term organic and mineral fertilizer application on yield and chemical composition of tops and tubers of potatoes. Potato Abst. 21 (4): 179.

Borin, M.; C. Giupponi and F. Osele. 1987. The effect of organic and mineral fertilizer and soil type on potato tuber formation. Information Agrasio. 43: 91-92 (c.a. Field Crop Abst. 4, 8072, 1987).

Bremner, J.M. 1965. Nitrogen availability indexes. In C.A. Blact et al. (ed.). Methods of Soil Analysis. Part 2. Agronomy. 9: 1324-1345.

Brijlal, S. and P. Sharma. 1995. Response of potato (Solanum tuberosum, $\mathrm{L}$ ) to potassium application in mid-hill soils of Himachal Pradesh. Indian Journal of Agricultural Sciences. 65 (6): 433-434. (c.a. Field Crop Abst., 49: 8222).

CoStat Software. 2004. User's Manual Version. Cohort Tusson, Arizona. USA. htti// www. Cohort.com ., info @ cohort . com.

Danilchenko, V.; R. Dris and A. Niskanen. 2005. Influence of organic and mineral fertilization on yield, composition and processing quality of potatoes. Journal of Food Agriculture \& Environment. 3(1): 143-144.

Das, S.K. and N.C. Banerjee. 1996. Nutrient uptake of crops and fertility status of soil at different manorial treatments under potato based crop sequences. Potato Abst., 21 (4): 180.

Efremov, V. and L.N. Samoilov. 1985. Efficiency of mineral fertilizers and FYM fertilizers in a crop rotation on a dernopodzolic soil Khimiya V sel's kom khozyaistiv. 23 (3): 17-18. (c.a. Field Crop Abst., 39: 841).

Eiecharczyk, A. and I. Malecka. 2000. Response of potato to organic and mineral fertilizer in a long-term experiment. No. 48, (84): 41-45. (c.a. CAB International Abst.).

El-Morsy, A.H.A.; E.N. El-Banna and M.M.B. Shokri. 2006. Effect of some sources of organic manures and foliar spray with some micronutrients on productivity and quality of potato. J. Agric. Sci. Mansoura Univ. 31 (6): 3859-3868.

El-Nashar, A.T.; M.M. Abdalla; M.N. Kandeel and S.A. Abdel-Aal. 1995. Effect of seed tuber size of some potato cultivars on productivity of autumn plantation. Assiut J. of Agric. Sci. 26 (2): 1-11

El-Sirafy, Z.M.; K.A. Abbady; A.M. El-Ghamry and R.A. ElDissoky. 2008. Potato yield quality, quantity and profitability as affected by soil and foliar potassium application. Research Journal of Agriculture and Biological Sciences. 4 (6): 912-922.

Filip, Z. and H. P. Muller. 1984. Effect of fermentation residus on soil micro-organism and some soil properties, a pot experiment. Institute fur Wasser- BodenUrdlufthygiene des Bundesundh- Eistamtes. 26 (3): 220228. 
Gardener, F.D.; R.B. Pearce and R.L. Mitchell. 1985. Physiology of crop plants. The Iowa State Univ. Press., pp. 327.

Grewal, J.S. 1990. Fertilizer use in potato crop in northwestern hills of India-Present status and future strategies. J. Indian Potato Assoc. 17 (1-2): 102-112.

Jackson, M.L. 1973. Soil Chemical Analysis. New Delhi, India, Prentice-Hall, India.

Kabeel, S.M.A. and N.M. Hasanin. 2006. Increasing potato productivity grown in sandy soil through organic and biofertilizers applications. J. Agric. Sci. Mansoura Univ. 31 (2): 951-962.

Kadhim, A.k. 1986. Studies on the effect of the addition biogas manure on the microbial and enzymatic activities in soil . M.Sc. Thesis. Fac. Agric. Moshtohor, Zagazig Univ, Benha Branch., Egypt.

Karmanov, S.N. and V.A. Gushchiva. 1986. Rational use of litter-free farmyard manure. Kartofel'i Ovoshchi. 3: 18-19. (c.a. Field crop. Abst., 40, 2948).

Makaraviciute, A. 2003. Effect of organic and mineral fertilizers on the yield and quality of different potato varieties. Agro. Res. J. 1 (2): 197-209.

Malik, C.P. and M.B. Singh. 1980. Plant enzymology and histoenzymology. A Text Manual-Kalyani Publishers, New Delhi.India.

Marwaha, R.S. 1998. Evaluation of Indian and exotic potato cultivars for processing into French fries. J. of the Indian Potato Association. 25 (1-2): 61-65. (c.a. Field Crop Abst., $52: 5)$.

Moustafa, M.H. 1994. Microbiological studies on the management urban wastes. Ph.D. Thesis, Fac. Agric. Zagazig Univ., Egypt.

Rabie, A.R. 1996. Effect of some potato cultural practices on potato production for processing. M.Sc. Thesis. Fac. Agric. Ain Shams Univ. Egypt. Cairo.

Reche, H.; H. Schnier.; S.Nabwile and J. Qureshe. 1997. Responses of irsh potatoes (Solanum tuberosum, L.) to mineral and organic fertilizer in various agro-ecological environments in Kenya Experimental Agriculture. 331 (1): 91-102.

Reichbuch, I.; C. Hera; W. Copony and I.V. Ciobanu. 1989. Studies on long term fertilizer applications on potato, wheat and maize yield and on the agrochemical indices of the chernozem-like soils of Suceava. Fundulea, 57: 181199. (c.a. Potato Abst. 16: 1384).

Saghin, G, 1989. Effect of organic and mineral fertilizers on potato yield in the mountain zone of Suceana country. Certcetari Agronomic in Moldova. 22 (2): $71-74$ (c.a. Field crop Abst., 43: 7473).
Sarhan, S.H.; H.K. Zaki and E. N. El-Bana. 2004. Impact of organic and inorganic fertilization on yield, tuber contents and some heavy metals concentration in potato tubers. J. Agri. Sci. Mansoura Univ. 29 (5): 2753-2750.

Shafeek, M.R.; M. El-Dsuki and A.M. Shaheen. 2001. Growth and yield of some potato cultivars as affected by sources of fertilization. Egypt. J. Appl. Sci. 16 (4): 242-260.

Shelton, W.R. and Harper, H.J. 1941. A rapid method for the determination of total phosphorus in soil and plant material. Iowa State College, J. of Sci. 15: 403-413.

Singh, S.P. and V.S. Kushwah. 2006. Effect of integrated use of organic and inorganic sources of nutrients on potato (Solanum tuberosum, L.) production. Indian Journal of Agronomy. 51 (3): 1-2.

Singh, S.P.; V. Singh and R. Lakhan. 1996. Effect of phosphorus and farmyard manure application on yield, content and uptake of nitrogen, phosphorus and sulfur by potato (Solanum tuberosum, L.). Indian J. Agron. 41 (4): 630-632.

Sood, M; G. Shekhawat; S. Shurana; S. Pandey and V. Chandla. 1994. Effect of tillage and mode of farmyard manure application on potato growth and yield at shimla. Proceeding of National Symposium Held at Modipuram, during 1-3 March: 121-123.

Spoil, N.T. and L.S. Fedotova. 1987. Fertilizers and tuber quality. Kartofeli ovoshch'i 5:18 : 19. (c.a. Field Crop Abst., 41: 1349).

Steel, R.G.D. and J.H. Torrie, 1984. Principles and procedures of statistics. $2^{\text {nd }}$ ed., McGraw Hill Book Co. Inc. Singapore, pp. 172-177.

Striban, M.; C. Deliv.; C. Salontal; A. Moraru and A. Suhov. 1984. Effect of cultivation technology on photosynthetic pigments and carbohydrates content of potato.(c.a.Field Crop Abst. 38, 6668).

Swaminathan, V.; P. Jayapaut; K. Nanjan and B. Uthayakumar. 1999. Suitable variety of potato for the Nilgiri district of Tamil Nadu. Crop Research (1999). 17 (2): 216-218. (c.a. Field Crop Abst. 52 :8, 5885).

Tashkhodzhaev, A.T. 1985. Effect of organic fertilizer on potato yield and quality on sierozem soils. Agrokhimiya, No. 11: 71-75. (c.a. Potato Abst. 12: 313).

Toth,S.J.;A.L.Prince;A.WallaceandD.S.Mikkelsen.1948.

Rapid quantitative determination of eight mineral elements in plant tissue by systematic procedure involving use of flam photometer. Soil Sci.66:459-466.

Widdowson, F.V. and A. Penny. 1975. Results from experiments measuring the effect of large amounts of an NPK fertilizer on yield, tuber size and N, P and K contents of three potato varieties. J. Agric. Sci. Cambradge. 85: 515-525. 


\section{الملخص العربي}

تأثير التسميد العضوى والمعدلن المركب على النمو الخضرى والخصول ومكوناته والتركيب

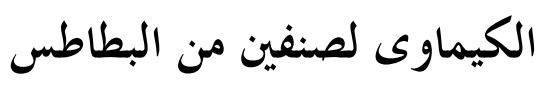

$$
\text { زهير محمود مرداد }
$$

- اتضح من النتائج ايضا ان صنف البطاطس"ديمونت" اعطى اعلى قيم للمتوسطات لاغلبية الصفات المدروسة خحلال الموسمين.

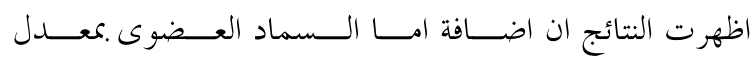

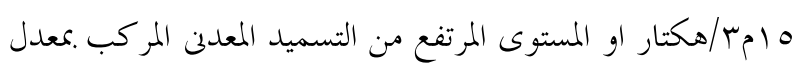

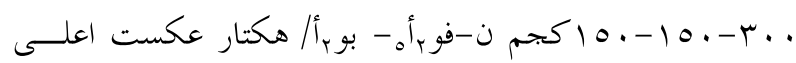

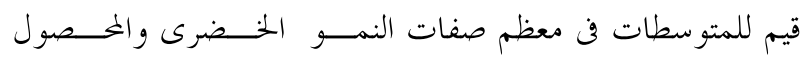
ومكوناته والمحتوى الكيماوى للبطاطس فن الموسمين الشتويين. بالنسبة للتاثر التداخل من النوع الاول عكــــت النتــائج ان

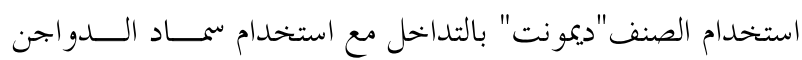
العضوى .معدل ه امب/هكتار او استخدام التسميد المعدلن المركب

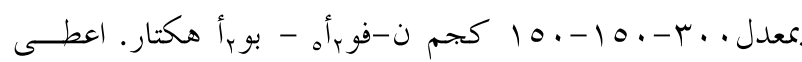
اعلى قيم لمتوسطات جميع صفات النمو الخضرى ومعظم صــفات

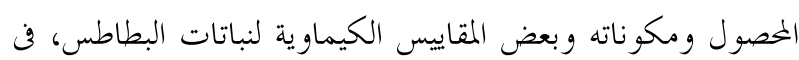

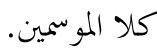
اتضح من النتائج ايضا ان معاملة التداخل من النــوع الثــانى باستخدام الصنف"ديونت" مع استخدام سماد الدواجن العــضوى معدل ه امب/هكتار بالاضافة الم استخدام التسميد المعدلى المركب

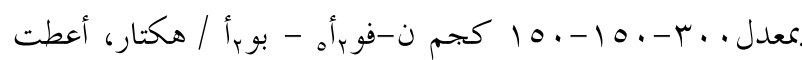

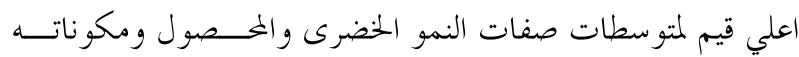

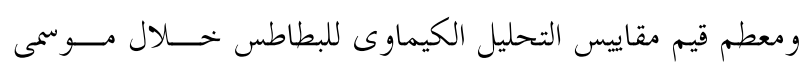

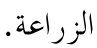

أجريت بتربتين حقليتين فن الموسمين الشتويين لعــامى ل . . ب و

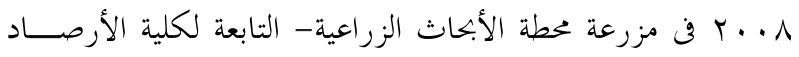

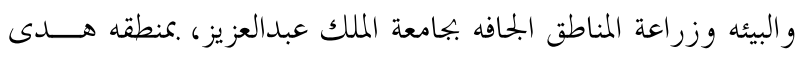
الشام،المملكة العربية السعودية، وذلك هِدف دراسة تأثيرات كـلـل من صنفين من البطاطس (نيكو لا - ديمونت)، ثلاث معدلات مــن سماد الدواجن العضوى(صفر - م 1، . م مب// هكتــار) والـسماد

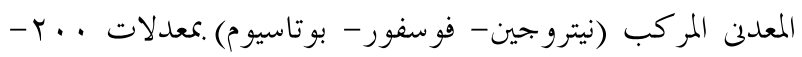

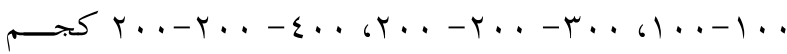
ن- فو ا هـ- بو | /هكتار بالإضافة إلى معاملة الكنتـــرول (بــــون

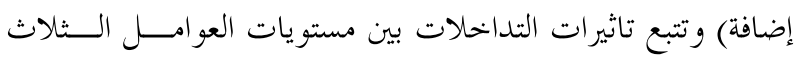

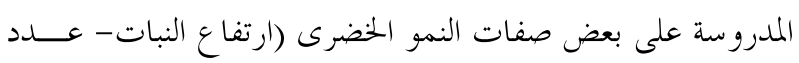
السيقان الهوائية- وزن الأوراق الطازج- النسبة المئوية للمادة الجحافة للأوراق)، كذلك صفات المصصول ومكوناته وهـــى (وزن الدرنــــ

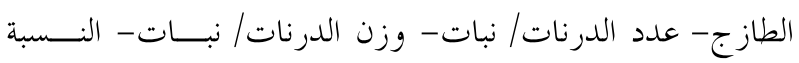
المئوية للمادة الجافة للدرنات) بالإضافة إلى تقدير بعض المكونــات

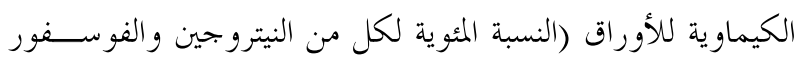
والبوتاسيوم) و كذلك للدرنات (النسبة المئوية للنشا والــسكريات الكلية، الكربوهيدرات) ويمكن تلخيص أهم النتائج المتحصل عليها فيما يلى : - اظهرت النتائج وجود فروق معنوية لقــيم معظــم الــصفات

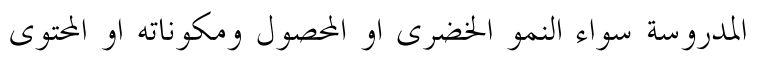
الكيماوى للاوراق والدرنات وذلك نتيجة تاثير كل عامل من

$$
\text { العوامل المدروسة، خلال موسمى الزراعة. }
$$

